\title{
Microbial and hydrothermal aspects of ferric oxyhydroxides and ferrosic hydroxides: the example of Franklin Seamount, Western Woodlark Basin, Papua New Guinea
}

\author{
T. D. Boyd $\dagger$ and S. D. Scott
}

Scotiabank Marine Geology Research Laboratory, Department of Geology, University of Toronto, Toronto, Ontario, Canada M5S3B1.E-mail: trevorb@arvotek.net

Received 15th June 2001, Accepted 17th August 2001

Article Published on the Web 5th September 2001

Deposits of $\mathrm{Fe}-\mathrm{Si}-\mathrm{Mn}$ oxyhydroxides are commonly found on the seafloor on seamounts and mid-ocean spreading centers. At Franklin Seamount located near the western extremity of Woodlark Basin, Papua New Guinea, Fe-Si-Mn oxyhydroxides are being precipitated as chimneys and mounds upon a substrate of mafic lava. Previous studies have shown that the vent fluids have a low temperature $\left(20-30^{\circ} \mathrm{C}\right)$ and are characterized by a total dissolved iron concentration of $0.038 \mathrm{mM} \mathrm{kg}^{-1}$, neutral $\mathrm{pH}(6.26)$ and no measurable $\mathrm{H}_{2} \mathrm{~S}$. The chimneys have a yellowish appearance with mottled red-orange patches when observed in situ from a submersible, but collected samples become redder within a few hours of being removed from the sea. The amorphous iron oxyhydroxides, obtained from active and inactive vents, commonly possess filamentous textures similar in appearance to sheaths and stalks excreted by the iron-oxidizing bacteria Leptothrix and Gallionella; however, formless agglomerates are also common. Textural relationships between apparent bacterial and non-bacterial iron suggest that the filaments are coeval with and/or growing outwards from the agglomerates. The amorphous iron oxyhydroxides are suggested to precipitate hydrothermally as ferrosic hydroxide, a mixed-valence $\left(\mathrm{Fe}^{2+}-\mathrm{Fe}^{3+}\right)$ green-yellow iron hydroxide compound. Consideration of the thermodynamics and kinetics of iron in the vent fluid, suggest that the precipitation is largely $\mathrm{pH}$ controlled and that large amounts of amorphous iron oxyhydroxides are capable of being precipitated by a combination of abiotic hydrothermal processes. Some biologically induced precipitation of primary ferric oxyhydroxides (two-XRD-line ferrihydrite) may have occurred directly from the fluid, but most of the filamentous iron microtextures in the samples appear to have a diagenetic origin. They may have formed as a result of the interaction between the iron-oxidizing bacteria and the initially precipitated ferrosic hydroxide that provided a source of ferrous iron needed for their growth. The processes described at Franklin Seamount provide insight into the formation of other seafloor oxyhydroxide deposits and ancient oxide-facies iron formation.

\section{Introduction}

Amorphous iron oxyhydroxides combined with variable amounts of manganese oxyhydroxides and silica are common in the oceans. ${ }^{1-3}$ but have not been as extensively studied as sulfide deposits. They are typically found in areas of volcanic activity such as at mid-ocean and back-arc spreading centers and on intraplate seamounts. Some are spatially associated with sulfide deposits, usually around the margins and, from their high base metal content, are clearly oxidation products of the sulfides. Others, the subject of this paper, were precipitated as oxides directly from hydrothermal fluids. These can form large deposits up to hundreds of meters across. They are found both in proximity to sulfide deposits and completely isolated from them. A distinctive characteristic is that, regardless of their location, these primary oxide deposits have a much lower content of base (except iron) and precious metals than those that have formed by oxidation of sulfides. ${ }^{3}$

Primary oxyhydroxide deposits cover extensive $>100 \mathrm{~m}^{2}$ areas of Franklin Seamount at 2143-2366 m water depth in Western Woodlark Basin, Papua New Guinea (Fig. 1). ${ }^{4,5}$ The basaltic andesite volcano straddles an active spreading center propagating westward into the Papua New Guinea continental margin. ${ }^{6,7}$ During the Soviet Union-Papua New GuineaAustralia-Canada (SUPACLARK) expedition in 1990, numerous actively venting oxyhydroxide chimneys and mounds were

$\dagger$ Present address: Millennium Minerals Corp., 350 Cleveland Street, Toronto, Ontario, Canada M4S 2W9. observed and sampled using the submersible Mir. Analysis of samples gathered from the Franklin Seamount deposits indicate they consist dominantly of amorphous iron oxyhydroxide (two-XRD-line ferrihydrite), locally contain major amounts of birnessite and nontronite, variable amounts of hydrothermal opal-A, variable amounts of incorporated volcanic and biologically-derived detritus, and minor vernadite and todorokite. ${ }^{8}$ No authigenic mixed-valence or ferrous iron is preserved in the samples.

The observation of the active creation of these chimneys together with their distinctive chemical composition characterized by a paucity of hydrothermally immobile elements such as $\mathrm{Al}$, Ti and $\mathrm{Zr}$ (ref. 3) suggests a primary abiotic hydrothermal control on the formation of these types of deposits. Conversely, close examination of similar materials by Juniper and Fouquet, ${ }^{9} \mathrm{Alt}^{10}$ and Fortin $^{11}$ found they possess complex filamentous micro-textures of apparent bacterial origin. The central role of filamentous bacteria in the precipitation of iron in acid mine drainage environments, ${ }^{12}$ subterranean environments ${ }^{13}$ and acidic surface hot springs ${ }^{14}$ is well known. Fortin and Ferris ${ }^{15,16}$ discussed the capability of bacteria to provide nucleation sites favorable for iron and manganese deposition. However, the importance of such sites, whether or not due to active metabolic processes, are apt to diminish under the nearneutral $\mathrm{pH}$ conditions of warm seafloor springs because kinetic barriers to the chemical precipitation of iron are greatly reduced at higher $\mathrm{pH} .{ }^{17}$ In general, both the microbial and abiotic chemical processes that occur at seafloor vent sites need to be considered in relation to the genesis of large amorphous 


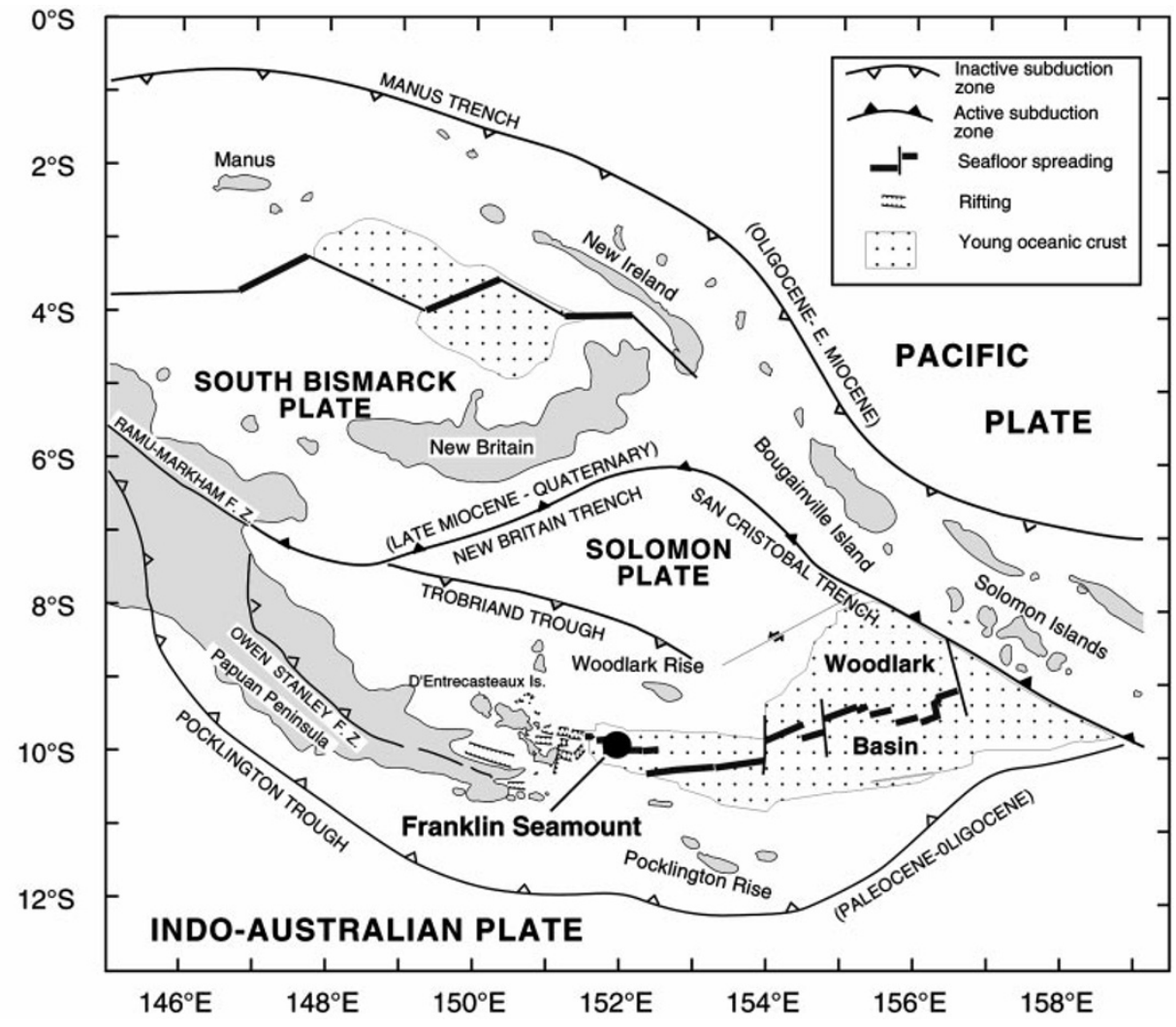

Fig. 1 Location map of Franklin Seamount, Western Woodlark Basin, Papua New Guinea. ${ }^{6,7}$

iron oxyhydroxide deposits because the free energy of crystal nucleation (and thus precipitation) is constrained thermodynamically by the bulk free energy of the solution and the interfacial free energy of available surfaces. ${ }^{16,17}$ Their study is important because such marine deposits are similar in their chemistry and geological setting to many ancient iron formations found on land. ${ }^{8,18}$

Iron, because of its multi-valent nature, is a sensitive indicator of its redox environment thus its behavior at the seafloor sediment/water interface can serve as a tool to understanding the physicochemical conditions for the precipitation of the oxyhydroxides at Franklin Seamount. This paper presents mineralogical, chemical and morphological information on the oxyhydroxides from Franklin Seamount that is interpreted in light of the thermodynamics and kinetics of low temperature hydrothermal iron systems, systematics of vent fluid chemistry and previous research on bacterial processes and habitats. These interpretations are used to explain the precipitation of iron locally around the vent site and to make comparisons with analogous environments associated with the precipitation of iron such as in other seafloor locations, soils and ancient iron formations.

\section{Method of investigation}

The samples for this study were collected by submersible and consist essentially of amorphous iron oxyhydroxides. Once on board the ship, the raw wet samples were placed into plastic containers or bags and the material was not dried until it was being prepared for laboratory study a few months later. Nothing was done to preserve possible organic remains in the samples so observed textures attributed to such are fossils.

The air-dried samples were first examined by light microscopy. This was followed by examination by scanning electron microscope (SEM) with an attached energy dispersive spectrometer (EDS). The SEM was operated at 15 to $25 \mathrm{kV}$ with magnifications of 1000 to 12,000 . Carbon coating of many of the samples considerably improved the quality of the images. A transmission electron microscope (TEM) equipped with an EDS was used to examine individual grains at higher magnifications of 10,000 to 200,000 at $200 \mathrm{kV}$. Grains were also characterized by selected area electron diffraction (SAED).

The observations were interpreted with reference to phase relations in the low temperature portion of the $\mathrm{Fe}-\mathrm{Si}-\mathrm{O}-\mathrm{H}$ system. A model of the hydrothermal system at Franklin Seamount was constructed by calculating the expected thermodynamic mineral equilibria for an actively venting amorphous iron oxyhydroxide chimney within an oxygenated seawater environment using the measured composition of a vent fluid obtained during the SUPACLARK cruise (Table 1). The thermodynamic database is discussed separately. The SUPCRT92 program ${ }^{19}$ was used to calculate expected changes in thermodynamic parameters at conditions other than $25^{\circ} \mathrm{C}$ and 1 bar. In addition, the kinetics of iron precipitation within this environment was estimated as a guide to ascertaining the relative roles of hydrothermal vs. biotic processes.

\section{Description of samples}

The actively venting oxyhydroxide chimneys at Franklin Seamount, as seen in situ from a submersible, commonly have a yellowish appearance with reddish orange patches that become more common towards their inactive bases (Fig. 2a, see also Fig. 5a, b in ref. 5). These observations have been corrected for the color changes caused by the longer wavelengths in the visible light spectrum being filtered out by seawater. Chimney samples removed from the water were observed to change to dark brown and reddish hues on the deck of the ship within a few hours of exposure to the atmosphere (Fig. 2b, see also Fig. 5d, 6a, c in ref. 5).

The samples are very friable with a roughly laminated to stromatolitic to porous, clotted texture (Fig. 2b). Amorphous iron oxyhydroxides are commonly coated by the black Mn 
Table 1 Chemistry of low temperature vent fluid sample from Franklin Seamount, Woodlark Basin. All data from Binns et al. ${ }^{5}$

\begin{tabular}{|c|c|c|}
\hline & Vent fluid & Ambient seawater \\
\hline$T /{ }^{\circ} \mathrm{C}$ & $20-30$ & 2.1 \\
\hline $\mathrm{pH}$ & 6.26 & 7.57 \\
\hline Alkalinity/u equiv $1^{-1}$ & 3.08 & $2.86-2.91$ \\
\hline \multicolumn{3}{|l|}{ Conc. $/ \mathrm{mM} \mathrm{kg}^{-1}$} \\
\hline $\mathrm{Mg}$ & 51.96 & $52.66-52.99$ \\
\hline $\mathrm{Ca}$ & 10.47 & $9.85-9.87$ \\
\hline $\mathrm{Si}$ & 0.33 & $0.117-0.118$ \\
\hline $\mathrm{Li}$ & 0.036 & 0.026 \\
\hline $\mathrm{Mn}$ & 0.010 & $2.5 \times 10^{-6}-4.5 \times 10^{-6}$ \\
\hline $\mathrm{Fe}$ & 0.038 & $4 \times 10^{-6}$ \\
\hline $\mathrm{Cl}$ & 532.9 & $530-531$ \\
\hline $\mathrm{H}_{2} \mathrm{~S}$ & $\mathrm{ND}^{a}$ & ND \\
\hline $\mathrm{NO}_{3}$ & 23.8 & $35.8-37.7$ \\
\hline $\mathrm{NO}_{2}$ & $<0.1$ & ND \\
\hline $\mathrm{NH}_{4}$ & 7.5 & ND \\
\hline $\mathrm{PO}_{4}$ & 0.78 & $2.6-2.9$ \\
\hline \multicolumn{3}{|l|}{ Conc. $/ \mu \mathrm{M} \mathrm{kg}^{-1}$} \\
\hline $\mathrm{Ni}$ & 0.014 & 0.006 \\
\hline $\mathrm{Cu}$ & 0.78 & $0.012-0.046$ \\
\hline $\mathrm{Zn}$ & 0.38 & ND \\
\hline \multicolumn{3}{|l|}{ Conc./nM kg ${ }^{-1}$} \\
\hline $\mathrm{Ag}$ & 0.23 & $0.09-0.18$ \\
\hline $\mathrm{Pb}$ & 1.2 & $0.38-0.48$ \\
\hline
\end{tabular}
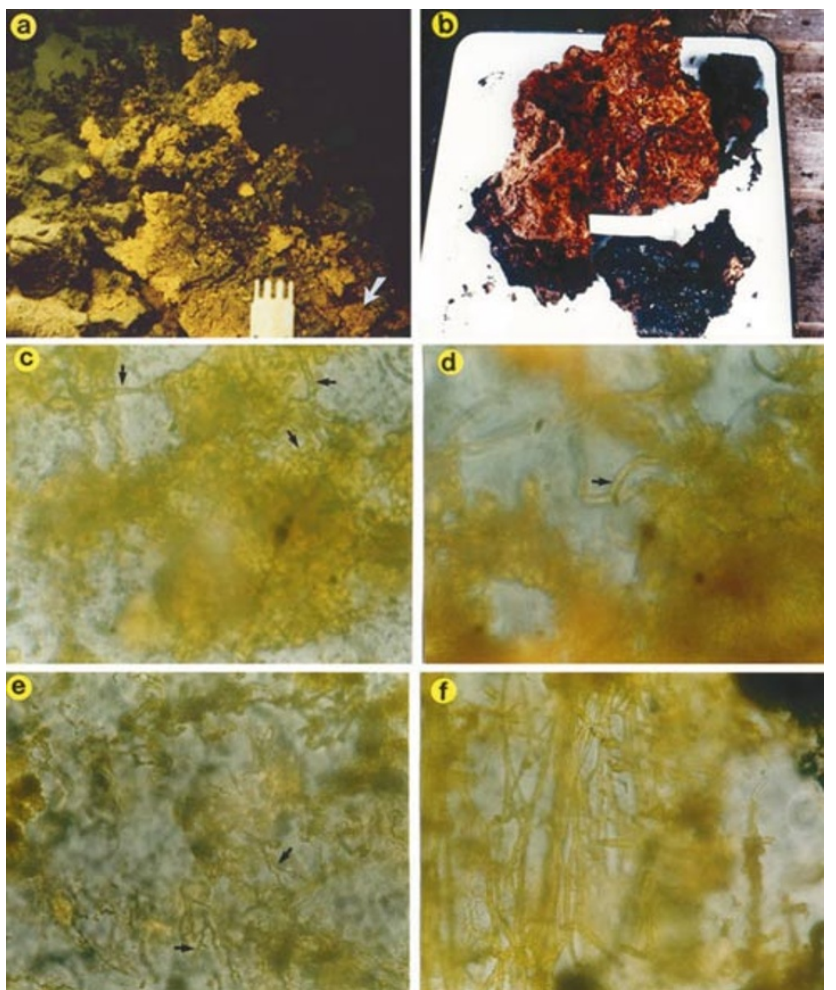

Fig. 2 Photographs of $\mathrm{Fe}-\mathrm{Si}-\mathrm{Mn}$ oxyhydroxides at Franklin Seamount. (a) In situ fresh staghorn chimney spire taken from submersible. Note the mottled pale color of the oxyhydroxides becomes more reddish towards the base (see arrow). (b) hand sample of oxyhydroxide taken on ship deck exhibiting red ferric iron with a sooty black manganiferous exterior. Photographs $2 \mathrm{a}$ and $\mathrm{b}$ courtesy of Raymond Binns, CSIRO, Australia. Thin section photographs of $\mathrm{Fe}-\mathrm{Si}-\mathrm{Mn}$ oxyhydroxides from Franklin Seamount. (c) and (d) iron mineralization attached to hair-like structures, sample M2192 loc. 1 (106848), note the faint outline of the filaments in association with the structures (see arrows), height of images $70 \mu \mathrm{m}$. (e) Filaments exhibiting a branching morphology (see arrows), sample M2157-14a (106893), height of image $70 \mu \mathrm{m}$. (f) Filaments exhibiting a bunched morphology, M2157-14a (106893), height of image $170 \mu \mathrm{m}$. oxyhydroxides, birnessite and todorokite. Dark green nontronite is found in the interiors of some samples although distinctive bright green patches were also observed from the submersible on the surface of an actively forming chimney near the vent orifice. ${ }^{5}$ These bright green patches are suggestive of ferrous trioctahedral smectite, a reduced precursor to nontronite. ${ }^{20}$

In thin section, the amorphous iron oxyhydroxide exhibits a complex mottled structure of hair-like strands or scattered circular patches together with filaments of probable biological origin that appear to emanate from the strands and patches (Fig. 2c, d). The filaments have a sinuous, apparently branching, morphology (Fig. 2e), or have the appearance of bunched streamers (Fig. 2f). The textures in Fig. 2 suggest that the ironrich material forms a coating.

SEM photographs clearly show the distinctive, apparently branching, filamentous micro-texture (Fig. 3a). The filaments
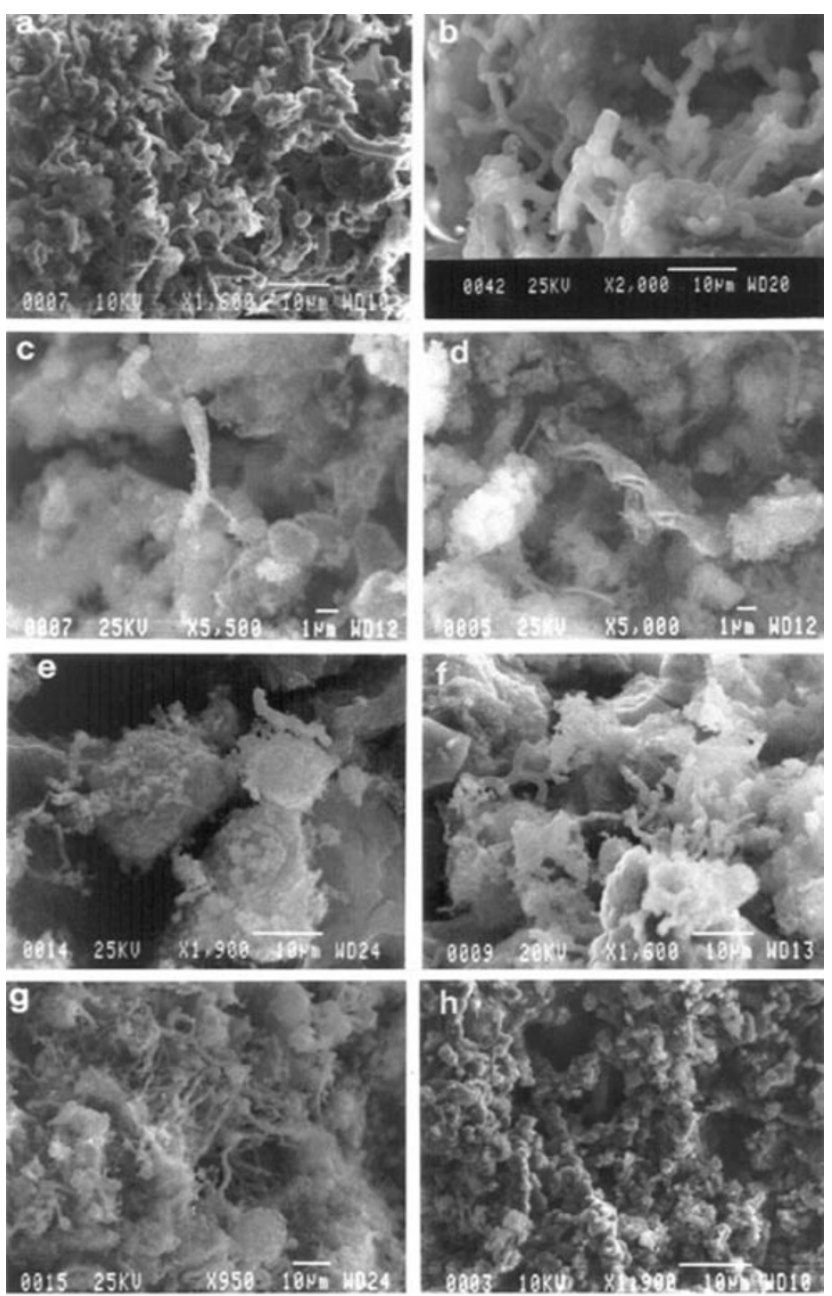

Fig. 3 SEM images of Fe-Si-Mn oxyhydroxides from Franklin Seamount. (a) Typical filamentous texture, sample M2170-8 (106905). (b) Apparently branching filaments thickened by silica carapaces (see arrow), sample M2202-6 (106925), photograph courtesy of Katsumi Marumo, Geological Survey of Japan, Japan. (c) Bunched filament made of parallel strands surrounded by amorphous iron agglomerates (see arrow), sample M2202-2a-1 (106920). (d) Short braided stalk in center (see arrow) surrounded by amorphous iron oxyhydroxides, M2202-2a-1 (106920). (e) Formless agglomerates of amorphous iron oxyhydroxide, sample M2202-2a-1 (106920). (f) and (g) Filaments (see arrows) attached or growing outwards from agglomerates of amorphous iron oxyhydroxide, M2192 loc. 1 (106848). Spot energy dispersive spectroscopy analyses show no significant compositional difference between the filamentous and formless textures. (h) Degraded filaments, M2170-2B (106899). Note the lack of degradation in those filaments adjacent to the formless textures in (c), (d), (f) and (g); these textures are very different from $(\mathrm{h})$. 
are $5-15 \mu \mathrm{m}$ long and 0.8 to $2 \mu \mathrm{m}$ wide but thicken to up to $5 \mu \mathrm{m}$ where coated with silica (Fig. $3 \mathrm{~b}$ ). Less common are some filament types that appear to be bunched into parallel strands (Fig. 3c) or short twisted and braided stalks (Fig. 3d). Fig. 3c, d and eof samples from an actively venting chimney also show that much of the iron oxyhydroxide appears to consist of formless agglomerates made up of irregularly shaped blebs which surround the filaments. In some samples, filaments appear to have grown out of the agglomerates (Fig. 3f, g).

It is difficult to determine if samples containing voluminous apparently non-bacterial agglomerates are just masked filamentous textures. This is probably not the case because the observed filaments in such samples do not appear to be especially thickened by additional iron oxyhydroxide deposition (Fig. 3a, c, d, e, f, g). Filaments in some samples appear to be degraded making their distinction from the formless microtextures uncertain (Fig. 3h). However, Fig. 3d, e, f, and g show non-degraded filaments adjacent to the formless blebs. These images are different from that exhibited in Fig. 3h. No evidence was found for formless micro-textures replacing degraded filaments.

Examination of the samples at higher magnifications by TEM reveals the sinuous pseudo-branching habit of the filaments identified by SEM (Fig. 4c) as well as several other features. Filaments have a hollow structure with rough walls consisting of bands of amorphous iron oxyhydroxide parallel to the long axis (Fig. 4d). The twisted stalks observed by SEM (Fig. 3d) are made up of $<0.5 \mu \mathrm{m}$ interwoven strands (Fig. 4e). Amorphous iron oxyhydroxide coats the walls of some filaments (Fig. 4f) but most of the individual filaments contain

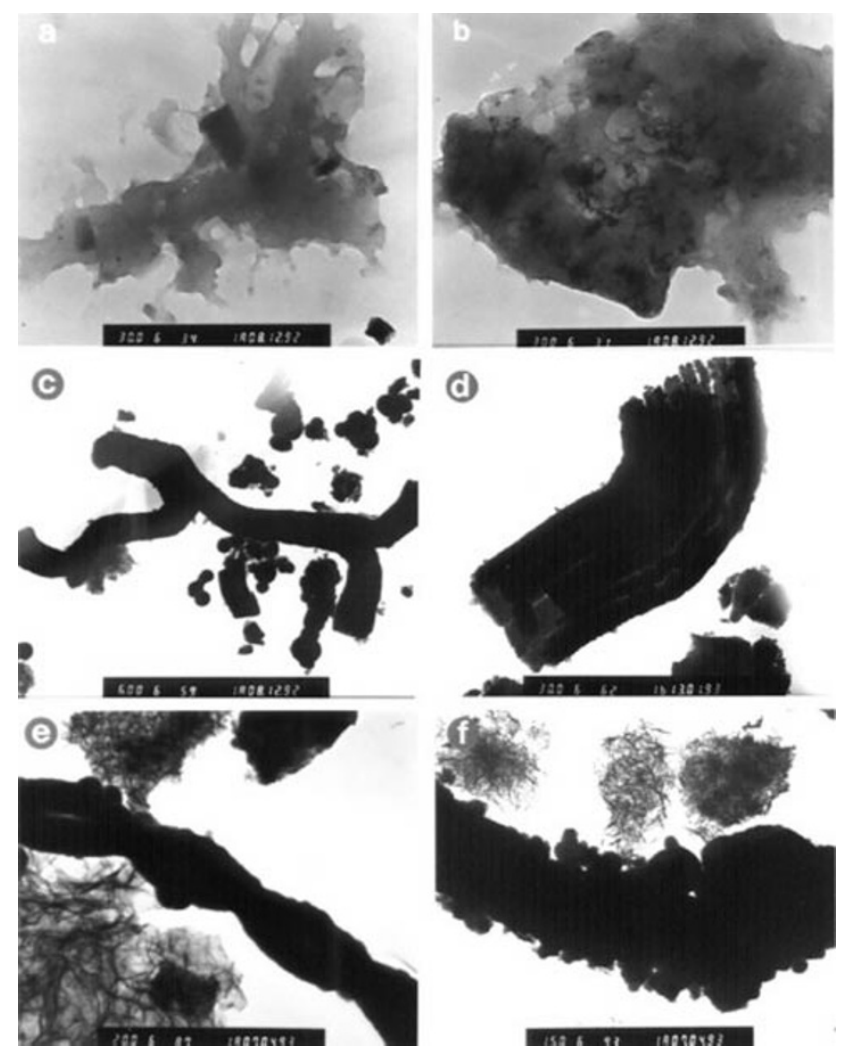

Fig. 4 TEM images of microbial forms in $\mathrm{Fe}-\mathrm{Si}-\mathrm{Mn}$ oxyhydroxides from Franklin Seamount. (a) and (b) Typical fragments of anhedral agglomerates of amorphous iron oxyhydroxides, sample M2202-2A-1 (106920), height of images $2.6 \mu \mathrm{m}$. (c) Pseudo? branching filament, sample M2022-3B (106926), height of image $13 \mu \mathrm{m}$. (d) Filament exhibiting hollow structure, sample M2192 loc. 1 (106848), height of image $2.6 \mu \mathrm{m}$. The walls consist of regular bands of amorphous ironsilica oxyhydroxides. (e) Braided filament, sample M2202-2a-1 (106920), height of images $4 \mu \mathrm{m}$. (f) Amorphous iron oxyhydroxides (see arrow) agglomerated on a typical filament, sample M2202-2a-1 (106920), height of images $5 \mu \mathrm{m}$. relatively little additional iron deposition on their walls so it is thought that such iron is accidental.

In summary, the amorphous iron oxyhydroxide in the samples displays a variety of morphologies that can be divided into three groups: (1) morphologies which appear to form or mold the walls of filamentous and/or stalked structures (Fig. 3a, b, c, d, and 4c, d, e); (2) morphologies which form discrete irregularly shaped formless agglomerates (Fig. 3c, d, e, f); and (3) morphologies which appear to have accumulated on the walls of the filaments and stalks (Fig. 4f). The first two groups are more abundant but their proportions are highly variable from sample to sample. The second group predominates in freshly precipitated material sampled from the actively venting part of a chimney, whereas nearly all of the material appears to be filamentous in samples from other parts of active chimneys and from inactive chimneys.

\section{Iron oxidizing bacteria}

The sample of a low temperature $\left(20-30^{\circ} \mathrm{C}\right)$, slightly acidic (pH 6.26) fluid, obtained from an actively venting chimney at Franklin Seamount (Table 1), allows physical and chemical constraints to be placed on the types of iron oxidizing bacteria that should thrive in the vent environment. Fig. 5 shows the redox conditions for common iron bearing compounds together with favorable environments for the growth of various genera of iron oxidizing bacteria. Lundgren and Dean ${ }^{21}$ noted that iron-rich substrates such as iron carbonates and sulfides nurture Leptothrix and Gallionella under conditions of neutral $\mathrm{pH}$ and medium to low $f\left(\mathrm{O}_{2}\right)$. The bacterial genus Leptothrix produces filamentous sheaths that can become heavily encrusted with hydrated ferric and manganic oxyhydroxides.

A sheath is defined as a hollow cylindrical structure made up predominantly of encrusted iron and possibly manganese oxyhydroxides that surrounds a chain of cells. It is closely fitting but not in intimate contact with the cells so the bacterium may move out leaving behind a preserved cast. ${ }^{22}$ The width, length and rough surface of the described filaments suggest that Leptothrix is the most common genus at the Franklin Seamount vent sites.

The samples from Franklin Seamount contain very little organic carbon ( 0.18 to $0.94 \mathrm{wt} . \% \mathrm{C}_{\text {org }}$, ref. 4 ), so it is probable that the organisms had died and decomposed, leaving behind their fossil form. Submersible observations of the chimneys and shipboard examination of the samples found no indication of macro-biological activity except for a few worm casts. ${ }^{4,5}$ The genus Gallionella is identified at the vent sites by its spirally

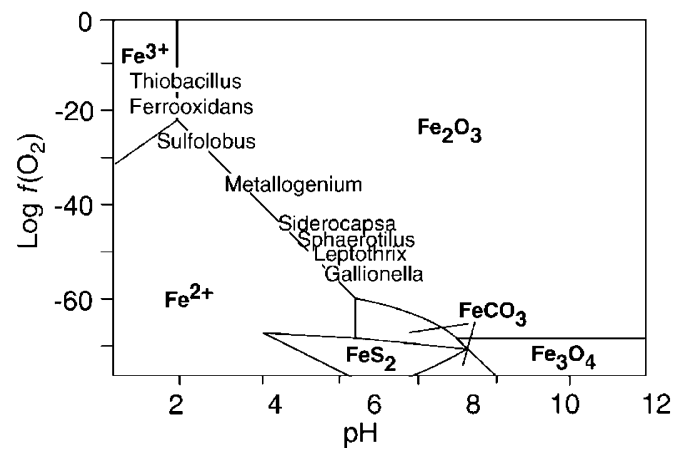

Fig. $5 f\left(\mathrm{O}_{2}\right)$ vs. $\mathrm{pH}$ iron stability diagram at $25^{\circ} \mathrm{C}$ and 1 bar showing the natural domains of the main groups of iron oxidizing bacteria recalculated from an $\mathrm{Eh}-\mathrm{pH}$ diagram in Lundgren and Dean. ${ }^{21}$ Activities of dissolved iron, carbonate, and sulfur species are $10^{-6}, 10^{0}$ and $10^{-6}$, respectively, from Garrels and Christ. ${ }^{75}$ The boundary between $\mathrm{Fe}^{3+}$ and $\mathrm{Fe}^{2+}$ which is missing in the Lundgren and Dean diagram, has been added here. Other thermodynamic databases suggest the presence of $\mathrm{FeHCO}^{+3}$ supplanting siderite between 6.4 and $7.0 \mathrm{pH}$ and acetates supplant other phases and species below $-75 \log f\left(\mathrm{O}_{2}\right)$. 
Table 2 Gibbs free energies of low temperature iron and silica oxyhydroxides in the system $\mathrm{Fe}-\mathrm{Si}-\mathrm{O}-\mathrm{H}$ at $25^{\circ} \mathrm{C}$ and 1 bar

\begin{tabular}{|c|c|c|c|c|c|}
\hline & $\begin{array}{l}\text { Sadiq and Lindsay, } \\
\left.1979 \text { (ref. }{ }^{39}\right) \\
\text { kcal mole }^{-1}\end{array}$ & $\begin{array}{l}\text { Ponamperuma } \\
\text { et al., } 1967 \text { (ref. } 25) \\
\text { kcal mole }^{-1}\end{array}$ & $\begin{array}{l}\text { Langmuir, } \\
1969 \text { (ref. } 36^{-1} \\
\text { kcal mole }^{-1}\end{array}$ & $\begin{array}{l}\text { Winters and Buckley, } \\
1986\left({ }^{\text {ref. } 43}\right) \\
\text { kcal mole }^{-1}\end{array}$ & $\begin{array}{l}\text { SUPCRT92, Johnson } \\
\text { et al., } 1991 \text { (ref. 19) } \\
\text { kcal mole }^{-1}\end{array}$ \\
\hline $\mathrm{Fe}^{3+}(\mathrm{aq})$ & -4.02 & - & -4.02 & - & -4.12 \\
\hline $\mathrm{Fe}^{2+}(\mathrm{aq})$ & -21.80 & -20.3 & -21.8 & -18.85 & -21.87 \\
\hline $\mathrm{Fe}(\mathrm{OH})_{2}(\mathrm{~s})$ & -117.584 & -115.6 & -117.584 & -116.3 & - \\
\hline $\begin{array}{l}\mathrm{Fe}(\mathrm{OH})_{3}(\mathrm{~s}) \text { soil amorphous } \\
\text { ferric iron }\end{array}$ & -170.250 & - & - & - & - \\
\hline $\begin{array}{l}\mathrm{Fe}(\mathrm{OH})_{3}(\mathrm{~s}) \text { aged amorphous } \\
\text { ferric iron }\end{array}$ & -170.163 & - & - & - & - \\
\hline $\begin{array}{l}\mathrm{Fe}(\mathrm{OH})_{3}(\mathrm{~s}) 4 \text { day old amorphous } \\
\text { ferric iron }\end{array}$ & -169.250 & - & -169.040 & - & - \\
\hline $\begin{array}{l}\mathrm{Fe}(\mathrm{OH})_{3} \text { (s) freshly precipitated } \\
\text { amorphous ferric iron }\end{array}$ & Nature uncertain & -166.0 & -167.460 & -166.5 & - \\
\hline $\begin{array}{l}\mathrm{Fe}_{3}(\mathrm{OH})_{8}(\mathrm{~s}) \text { freshly precipitated } \\
\text { amorphous mixed-valence iron }\end{array}$ & -459.220 & $\begin{array}{l}-451.2 \\
\text { (nature uncertain) }\end{array}$ & - & - & - \\
\hline $\mathrm{H}_{2} \mathrm{O}$ & -56.687 & -56.7 & -56.688 & -56.69 & -56.688 \\
\hline $\mathrm{OH}^{-}$ & -37.594 & - & -37.594 & - & -37.595 \\
\hline $\mathrm{SiO}_{2}$ amorphous & -203.02 & - & - & -202.89 & $-202.89\left(\mathrm{SiO}_{2}-n \mathrm{H}_{2} \mathrm{O}\right)$ \\
\hline Ferrosilite & -257.6 & - & - & -267.16 & -267.16 \\
\hline $\mathrm{Si}(\mathrm{OH})_{4}(\mathrm{aq})$ & -312.66 & - & - & - & $-312.6\left(\mathrm{SiO}_{2}[\mathrm{aq})\right]$ \\
\hline
\end{tabular}

twisted stalk structure (Figs. 3d and 4e) formed by the rotation of the individual filaments of its apical cells. ${ }^{23}$

In summary, the morphologies of ferric iron casts suggest that the iron oxidizing bacteria Leptothrix and Gallionella once thrived within the iron oxyhydroxide chimneys at Franklin Seamount. A near neutral $\mathrm{pH}$, low $f\left(\mathrm{O}_{2}\right)$ and ferrous iron-rich vent fluid combined with a seawater environment rich in organic carbon favored the growth of these genera. Recognition of the casts made by these genera, and specifically the textures of the manganese and iron, is good evidence that microbially mediated deposition of iron is occurring at Franklin Seamount.

\section{Geochemical considerations}

\section{Iron}

We postulate that, at the low temperatures of the vent fluids, chemical reactions involving iron phases are controlled by reaction kinetics which slow the attainment of true equilibria in these systems. In order to account for this thermodynamically, Lindsay $^{24}$ and Ponnamperuma et al. ${ }^{25}$ used the standard free energies of formation for unstable hydroxides rather than their crystalline counterparts when modeling the behavior of iron in soils at a temperature and $\mathrm{pH}$ similar to those of the vent fluids at Franklin Seamount. This is because, according to the Oswald step rule, an unstable phase does not necessarily transform directly to a stable phase, but may pass through successive intermediate phases due to there being lower activation energy barriers via that route. These intermediate unstable phases are preserved in the form of amorphous iron oxyhydroxides in both soils ${ }^{26}$ and in the submarine environment at Franklin Seamount. Iron has a greater solubility relative to amorphous iron oxyhydroxides than to their crystalline counterparts but the higher reactivity of the former results in their preferential precipitation from hydrothermal solutions. ${ }^{17}$

For the purposes of thermodynamic modeling, $\mathrm{Fe}(\mathrm{OH})_{3}$ or ferric hydroxide is used to describe unstable amorphous ferric oxyhydroxides or two-XRD-line ferrihydrite. This material is well characterized in the literature and displays a variety of brown to red colors depending on its crystallinity. ${ }^{27}$ The true composition of ferric hydroxide is uncertain and variable depending upon its crystallinity with proposed examples such as $\mathrm{Fe}_{5} \mathrm{HO}_{8} \cdot 4 \mathrm{H}_{2} \mathrm{O}$ (ref. 28), $\mathrm{Fe}_{5}\left(\mathrm{O}_{4} \mathrm{H}_{3}\right)_{3}$ (ref. 29), $5 \mathrm{Fe}_{2} \mathrm{O}_{3} \cdot 9 \mathrm{H}_{2} \mathrm{O}$ (ref. 27), $\mathrm{Fe}_{4}\left(\mathrm{O}, \mathrm{OH}, \mathrm{H}_{2} \mathrm{O}\right)_{12}$ (ref. 30) and ${ }^{\mathrm{VI}} \mathrm{Fe}_{2.9}{ }^{\mathrm{IV}}(\mathrm{Si}, \mathrm{Fe}, \mathrm{Al})_{1.3^{-}}$ $\left(\mathrm{O}, \mathrm{OH}, \mathrm{H}_{2} \mathrm{O}\right)_{12}$ (ref. 8).
$\mathrm{Fe}_{3}(\mathrm{OH})_{8}$ is used to describe a mixed-valence iron compound named ferrosic hydroxide. ${ }^{25,26,31}$ It is variable in color ranging from yellow to olive green to green-blue in $\operatorname{color}^{25,31,32}$ and is a major constituent in reduced iron-rich carbonate-poor soils. ${ }^{26,33}$ Ferrosic hydroxide is believed to be the unstable precursor to magnetite. ${ }^{25}$ Ferrosic hydroxide belongs to a variable and wide range of mixed valence compounds named green rusts for which general compositions have been proposed which vary from $\mathrm{Fe}_{2}(\mathrm{OH})_{5}$ (ref. 32) to $\left(\mathrm{Fe}^{11}{ }_{(1-x)} \mathrm{Fe}^{111}{ }_{x^{-}}\right.$ $\left.(\mathrm{OH})_{2}\right)^{x+}\left(x / n \mathrm{~A}^{n-} m / n \mathrm{H}_{2} \mathrm{O}\right)^{x-}$, (ref. 34) where $\mathrm{A}$ can be the anions $\mathrm{OH}^{-}, \mathrm{Cl}^{-}, \mathrm{CO}_{3}{ }^{2-}$ or $\mathrm{SO}_{4}{ }^{2-}$.

At Franklin Seamount, the dominance of amorphous iron oxyhydroxide was demonstrated by XRD and electron diffraction combined with bulk chemical and spot EDS analyses. ${ }^{8}$ Knowledge of the composition of the vent fluid at Franklin Seamount (Table 1, ref. 5) provides an opportunity to place constraints on the physico-chemical environment of the iron precipitation assuming the fluid and the minerals are in equilibrium.

Table 2 is a compilation of some of the available thermodynamic data applicable to low temperature $\mathrm{Fe}-\mathrm{Si}-\mathrm{O}-\mathrm{H}$ systems and Table 3 lists the equations used to model the system at $25^{\circ} \mathrm{C}$ and 220 bar (the pressure at $2200 \mathrm{~m}$ depth) at Franklin Seamount. There is considerable variability in the tabulated free energies of oxyhydroxide and oxide phases (Table 2). Experimental solubility measurements suggest that differences in particle size and crystallinity can account for as much as several kcal mole-1 in their free energy of formation. ${ }^{35}$ Langmuir ${ }^{36}$ estimated that free energy decreased with

Table 3 Reactions used to model the precipitation of low temperature iron and silica oxyhydroxides in the system $\mathrm{Fe}-\mathrm{Si}-\mathrm{O}-\mathrm{H}$ shown in Fig. 7

$\mathrm{Fe}(\mathrm{OH})_{3}$ (fresh ferric hydroxide) $(\mathrm{s})+2 \mathrm{H}^{+}=$ $\mathrm{Fe}^{2+}+5 / 2 \mathrm{H}_{2} \mathrm{O}+1 / 4 \mathrm{O}_{2}$

$\mathrm{Fe}_{3}(\mathrm{OH})_{8}$ (fresh ferrosic hydroxide) $+6 \mathrm{H}^{+}=$

$3 \mathrm{Fe}^{2+}+7 \mathrm{H}_{2} \mathrm{O}+1 / 2 \mathrm{O}_{2}$

$3 \mathrm{Fe}(\mathrm{OH})_{3}$ (fresh ferric hydroxide) $=$

$\mathrm{Fe}_{3}(\mathrm{OH})_{8}$ (fresh ferrosic hydroxide) $+1 / 2 \mathrm{H}_{2} \mathrm{O}+1 / 4 \mathrm{O}_{2}$

$\mathrm{Fe}_{3}(\mathrm{OH})_{8}$ (fresh ferrosic hydroxide $)=$

$3 \mathrm{Fe}(\mathrm{OH})_{2}$ (fresh ferrous hydroxide) $+\mathrm{H}_{2} \mathrm{O}+1 / 2 \mathrm{O}_{2}$

$\mathrm{Fe}(\mathrm{OH})_{2}$ (fresh ferrous hydroxide) $+2 \mathrm{H}^{+}=\mathrm{Fe}^{2+}+2 \mathrm{H}_{2} \mathrm{O}$

$\mathrm{SiO}_{2}$ (amorphous) $+2 \mathrm{H}_{2} \mathrm{O}=\mathrm{Si}(\mathrm{OH})_{4}$

$\mathrm{FeSiO}_{3}$ (ferrosilite) $+3 \mathrm{H}_{2} \mathrm{O}=\mathrm{Fe}(\mathrm{OH})_{2}$ (fresh ferrous hydroxide) + $\mathrm{Si}(\mathrm{OH})_{4}$

$\mathrm{FeSiO}_{3}$ (ferrosilite) $+10 \mathrm{H}_{2} \mathrm{O}+1 / 2 \mathrm{O}_{2}=$

$\mathrm{Fe} 3(\mathrm{OH})_{8}$ (fresh ferrosic hydroxide) $+3 \mathrm{Si}(\mathrm{OH})_{4}$

$\mathrm{FeSiO}_{3}$ (ferrosilite) $+\mathrm{H}_{2} \mathrm{O}+2 \mathrm{H}^{+}=\mathrm{Fe}^{2+}+\mathrm{Si}(\mathrm{OH})_{4}$ 
increase in grain size consistent with the trend of decreasing free energy from -169.25 to -170.40 to $-177.85 \mathrm{kcal}$ mole -1 and decreasing solubility of iron in water among materials of increasing crystallinity for $\mathrm{Fe}(\mathrm{OH})_{3}$ (amorphous iron hydroxide), $\mathrm{Fe}(\mathrm{OH})_{3}$ (in soil) and hematite, respectively. ${ }^{24,26}$ Fig. 6 shows the great difference in the calculated position of the phase boundary between $\mathrm{Fe}(\mathrm{OH})_{3}$ and $\mathrm{Fe}_{3}(\mathrm{OH})_{8}$ from $10^{-44}$ to $10^{-68}$ bar $f\left(\mathrm{O}_{2}\right)$ at Franklin Seamount, a range of 24 orders of magnitude depending upon the type of ferric iron hydroxide used and/or source of the data!

When choosing the appropriate thermodynamic parameters for the amorphous iron oxyhydroxides at Franklin Seamount, it should be noted that these phases are actively precipitating from hydrothermal fluids and thus are very fresh when initially deposited. Accordingly, the free energy values chosen to model the formation of ferrosic hydroxide (Table 2) were those obtained from the laboratory experiments of Arden, ${ }^{31}$ as these conditions are most similar to the vent conditions on the seafloor. The solubility product for this fresh ferrosic hydroxide was obtained by potentiometric titration. The phase was precipitated at room temperature from an initial ferrous iron solution under rising $\mathrm{pH}$, between $6.4-6.8$, with the addition of a ferric sulphate solution. Hansen et al. $^{37}$ repeated the experiment, obtained a similar titration curve and the material formed was identified as sulphate-interlayed green rust. Frederickson et al. ${ }^{38}$ concluded that the optimal $\mathrm{pH}$ range for the development of green rust is between 6.5 to 7.5. These conditions are similar to those in the low temperature vent fluid at Franklin Seamount so this value is incorporated in the thermodynamic database for soil phases given in Table 2 by Sadiq and Lindsay. ${ }^{39}$ Free energy values for ferric hydroxide $\mathrm{Fe}(\mathrm{OH})_{3}$ in the Lindsay database, such as those of Schindler et $a l^{40}$ and Sadiq and Lindsay ${ }^{39}$ were not considered because these were obtained on aged material whose conditions of formation are far removed from the vent conditions at Franklin Seamount.

Fig. 6 demonstrates that the fresher the $\mathrm{Fe}(\mathrm{OH})_{3}$ in

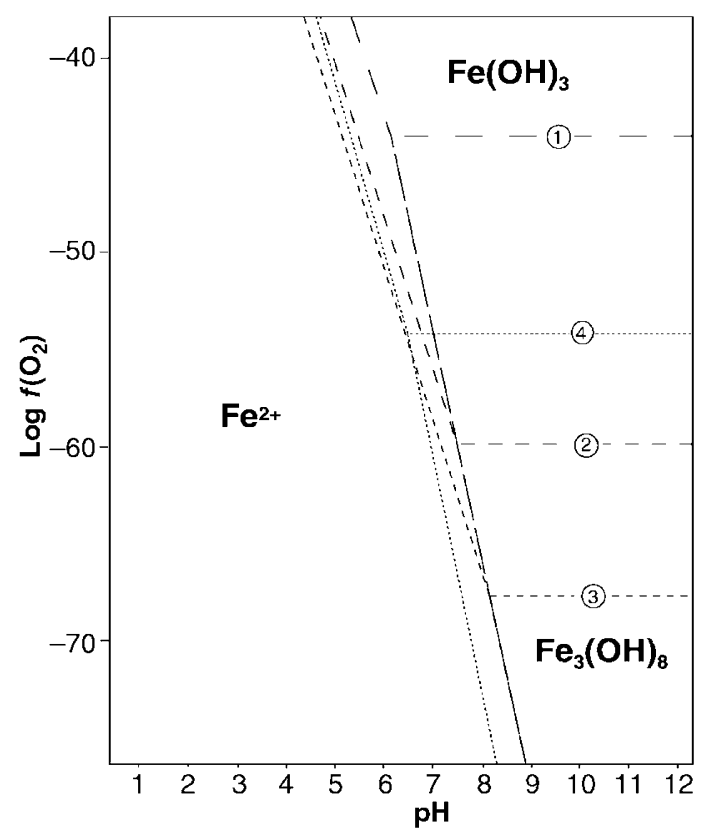

Fig. 6 Change in stability boundaries in $\mathrm{Fe}-\mathrm{O}-\mathrm{H}$ system with age of the amorphous iron oxyhydroxides at $25^{\circ} \mathrm{C}, 240$ bar and $\left[\mathrm{Fe}_{\text {total }}\right]=$ $3.9 \times 10^{-5} \mathrm{~m}$ calculated and based on the physical and geochemical conditions of the Franklin Seamount vent fluid reported in ref. 5. (1) Freshly precipitated $\mathrm{Fe}(\mathrm{OH})_{3}$, ref. 36. (2) 4-day old $\mathrm{Fe}(\mathrm{OH})_{3}$, ref. 39 and 40. (3) Aged $\mathrm{Fe}(\mathrm{OH})_{3}$, ref. 39. (4) Age of $\mathrm{Fe}(\mathrm{OH})_{3}$ unknown, ref. 25. Thermodynamic data for $\mathrm{Fe}_{3}(\mathrm{OH})_{8}$ is for freshly precipitated material. ${ }^{39}$ Calculated with aid from SUPCRT92 program. ${ }^{19}$ equilibrium with fresh $\mathrm{Fe}_{3}(\mathrm{OH})_{8}$, the higher the $f\left(\mathrm{O}_{2}\right)$ of the boundary between the two compounds. Since the free energy of amorphous materials has a negative correlation with grain size and because freshly precipitated primitive crystallites agglomerate together and grow in size with aging, it would be expected that the material's free energy would decrease as it becomes older. The free energy of formation provided by Langmuir ${ }^{36}$ for $\mathrm{Fe}(\mathrm{OH})_{3}$ in Table 2 was obtained from solubility experiments conducted on a freshly precipitated phase and it has the least negative free energy among the $\mathrm{Fe}(\mathrm{OH})_{3}$ compounds shown. For this reason, this value best matches the precipitation of amorphous ferric oxyhydroxides at Franklin Seamount. Dzombak and Morel $^{41}$ reported that freshly precipitated hydrous ferric oxyhydroxides are made up of spherical particles $10-100 \AA$ in size, similar to samples from the actively precipitating vents at Franklin Seamount described by Boyd and Scott. ${ }^{8}$

In summary, the free energy database of Sadiq and Lindsay, ${ }^{39}$ excepting the value for fresh $\mathrm{Fe}(\mathrm{OH})_{3}$ from Langmuir ${ }^{36}$ substituting for the value of the 4 day old material, is used here to model the mineral equilibria of amorphous iron oxyhydroxides at an actively venting chimney at Franklin Seamount as shown in Table 3.

\section{Silicon}

Silicon makes up on average $12.2 \mathrm{wt} . \%$ of the bulk samples and $7.0 \mathrm{wt} . \%$ of ferrihydrite from Franklin Seamount (the content of the iron end-member sample, M2192-loc. 1 106848, Boyd and Scott 1999, ref. 8) so the element must be incorporated into the thermodynamic model of the vent sites. Based on XRD patterns of all the collected samples, ${ }^{8}$ excepting two, discrete silica mineralization of hydrothermal origin appears to be minor. However, as a caution Cremer ${ }^{42}$ found for the oxyhydroxide deposits at Loihi Seamount that the XRD response to amorphous silica is commonly masked by the iron oxyhydroxide. In the two non-conforming samples from Franklin Seamount, amorphous silica mantles iron minerals having filamentous textures (Fig. 3b) in a manner similar to that described by Juniper and Fouquet ${ }^{9}$ for samples from Explorer Ridge and the East Pacific Rise. The dynamic depositional environment and low temperature of the vent fluids at Franklin Seamount promote the precipitation of unstable amorphous silica rather than quartz in a similar fashion to the behavior of iron.

In general, the relative scarcity of amorphous silica phases at Franklin Seamount can be explained by the silicon content of the vent fluid (Table 1), which is calculated to be undersaturated with respect to amorphous silica by a factor of 5 at a temperature of $25^{\circ} \mathrm{C}$. The presence of nontronite in the samples at Franklin Seamount, however, suggests that the silicon in the fluid does exert some control on the mineralogy of the deposits. Thermodynamic data for the phase ferrosilite $\left(\mathrm{FeSiO}_{3}\right)$ in the Winters and Buckley ${ }^{43}$ compilation (originally from Helgeson et al. $^{35}$ in Table 2 is used to represent nontronite. This is a reasonable substitute provided the iron in nontronite is initially ferrous. Harder ${ }^{44}$ synthesized a ferrous trioctahedral smectite precursor to nontronite under $\mathrm{Eh}-\mathrm{pH}$ conditions similar to those for which ferrosilite was expected, but was not successful in precipitating lembergite at higher Eh or lower $\mathrm{pH}$.

\section{Oxygen and hydrogen}

The $f\left(\mathrm{O}_{2}\right)$ of the vent fluid is not known but is believed to be much lower than that of seawater (0.06 atm at $2000 \mathrm{~m}$ depth). ${ }^{45}$ End-member hydrothermal vent fluids at $>300^{\circ} \mathrm{C}$ are extremely acidic before mixing with seawater. ${ }^{46,47}$ As the fluid cools, whether by mixing with seawater or conduction, the $\mathrm{pH}$ steadily increases and element concentrations decrease with the precipitation of phases. ${ }^{48}$ Hannington and $\mathrm{Scott}^{49}$ used 
mineral equilibria to model the decrease in $\log f\left(\mathrm{O}_{2}\right)$ from -32 to -43 as the fluid cooled from 350 to $180^{\circ} \mathrm{C}$ at $21^{\circ} \mathrm{N}$ East Pacific Rise and Axial Seamount. A strong redox buffering capacity between the $\mathrm{H}_{2} \mathrm{~S}$ in the vent fluid and $\mathrm{SO}_{4}$ in seawater was invoked to explain the down-temperature decrease in $f\left(\mathrm{O}_{2}\right)$ with the increased mixing of the fluid with the oxygenated bottom seawater. The authors suggested that below $180^{\circ} \mathrm{C}$, as the $\mathrm{H}_{2} \mathrm{~S}$ content of the fluid dropped with the precipitation of sulfides, the redox buffer broke down.

There are, however, other possible redox buffers which could become important. Reaction between $\mathrm{Fe}^{2+}$ in the fluid and the precipitated iron phases would cause the oxygen fugacity of the evolving vent fluid to continue to fall with increased mixing. The equations in Table 3 demonstrate that for a fluid precipitating an iron phase, such as shown by the univariant boundaries in Fig. 6, a rise in $\mathrm{pH}$ due to mixing with seawater is accompanied by a concurrent drop in $f\left(\mathrm{O}_{2}\right)$. The fluid would be held or buffered to that univariant line providing the $\mathrm{Fe}^{2+}$ is maintained in or close to mineral equilibria with the precipitating phases. These mineral equilibria would be maintained as long as the active vent was constantly replenishing ferrous iron to the system.

There have been no direct measurements of oxygen or Eh of vent fluids on the seafloor. However, it is likely that vent fluids at Franklin Seamount are considerably more reduced than seawater despite possessing no $\mathrm{H}_{2} \mathrm{~S}$ and being more than $90 \%$ diluted by seawater. Bowers et $a .^{48}$ thermodynamically modeled the cooling of end-member hydrothermal fluids by mixing with seawater and found that $\log f\left(\mathrm{O}_{2}\right)$ steadily falls to below -70 at $25^{\circ} \mathrm{C}$. The $f\left(\mathrm{O}_{2}\right)$ then climbs sharply back up in response to the ambient seawater flooding the system. The calculations indicate that all the sulfides are precipitated between 300 and $150{ }^{\circ} \mathrm{C}$ and yet the $f\left(\mathrm{O}_{2}\right)$ continues to drop at temperatures below $150^{\circ} \mathrm{C}$. Bowers et al. ${ }^{50}$ analysed the composition of high temperature vent fluids obtained from $11-13^{\circ} \mathrm{N}$ and $21^{\circ} \mathrm{N}$ and found that a $50 \%$ decrease in iron in solution accompanied by a $\mathrm{pH}$ rise can be accounted for by a $15^{\circ} \mathrm{C}$ drop in temperature and the buffering of the solution by greenschist-facies mineral assemblages. The authors found that vent fluid compositions at $21^{\circ} \mathrm{N}$ were uniform with respect to time, based upon expeditions in 1979, 1981 and 1985, and concluded that the compositions of vent fluids and especially the iron are controlled by equilibria with solid phases.

In conclusion, the low temperature redox conditions at Franklin Seamount are consistent with results of studies of higher temperature seafloor hydrothermal systems. These results support the contention that iron participates in the redox balance between the vent fluid and its precipitated products, and are consistent with iron phases commonly being the dominant mineralization in both high and low temperature modern hydrothermal deposits.

\section{Carbon and sulfur}

No analyses of carbon in the vent fluid are available from Franklin Seamount, however, the $\mathrm{pH}$ drifted from 6.1 to 6.26 when exposed to the atmosphere indicating probable exsolution of $\mathrm{CO}_{2}$ from the fluid. ${ }^{5}$ Based on the estimate that $P\left(\mathrm{CO}_{2}\right)$ of surface seawater in equilibrium with the atmosphere is $3.3 \times 10^{-4}$ bar, then doubling the $P\left(\mathrm{CO}_{2}\right)$ will lower the $\mathrm{pH}$ by 0.28 units. ${ }^{51} \mathrm{~A}$ drift of $0.16 \mathrm{pH}$ units therefore is consistent with an estimated $P\left(\mathrm{CO}_{2}\right)$ of $5.2 \times 10^{-4}$ bar for the vent fluid providing its overall composition is not considerably different from seawater, as is the case (Table 1). A $P\left(\mathrm{CO}_{2}\right)$ of at least $10^{-2}$ bar is required before iron carbonates such as siderite will start to precipitate in the hydrothermal system at Franklin Seamount. This is supported by the SEM and TEM examination of the samples that showed an absence of any hydrothermal carbonate minerals.

No $\mathrm{H}_{2} \mathrm{~S}$ was detected in the vent fluid so sulfur was not incorporated into the thermodynamic calculations. The low level of sulfur in the system is consistent with the absence of hydrothermal sulfur bearing minerals in the samples.

\section{Kinetic parameters}

Kinetic constraints on the hydrothermal precipitation of iron have been invoked by many researchers in proposing microbial mediation as an alternative explanation for the formation of voluminous iron oxyhydroxides on the seafloor. ${ }^{10,21}$ The rate of oxidation of ferrous iron in low temperature hydrothermal solutions is very slow. For example, at $\mathrm{pH}=5$ and $P\left(\mathrm{O}_{2}\right)=$ 0.06 bar (2000 $\mathrm{m}$ depth in seawater), the half-life for the oxidation of $\mathrm{Fe}^{2+}$ to $\mathrm{Fe}^{3+}$ is 30 years. ${ }^{10}$ The ferrous iron oxidation rate constant $(k)$ in seawater, determined by Millero et al. ${ }^{52}$ as a function of temperature $(T / \mathrm{K})$ and ionic strength (I) is:

$$
\log k=21.56-1545 / T-3.291(I) 1 / 2+1.52(I)
$$

Eqn. (1) is incorporated into an equation used to calculate the oxidation rate of iron as a function of $P\left(\mathrm{O}_{2}\right), \mathrm{pH}$ and the concentration of $\mathrm{Fe}^{2+}$ in the fluid: ${ }^{52}$

$$
-\mathrm{d}\left[\mathrm{Fe}^{2+}\right] / \mathrm{d} t=k\left[\mathrm{Fe}^{2+}\right]\left[\mathrm{O}_{2}\right]\left[\mathrm{OH}^{-}\right]_{2}
$$

The activity coefficient of $\mathrm{H}_{2} \mathrm{O}$ in seawater at $25^{\circ} \mathrm{C}$ and less than $1 \mathrm{kbar}$ pressure is 0.98 , the difference from unity being a function of ionic strength, so for the purposes of these calculations fugacity and activity are assumed to equal partial pressure and concentration, respectively.

The oxidation rate is extremely sensitive to changes in $\mathrm{pH}$. From eqn. (2), the half-life for the oxidation of ferrous iron is calculated to be $44 \mathrm{~min}$ for the $\mathrm{pH}$, temperature and iron concentration of the measured vent fluid at Franklin Seamount (Table 1) if that fluid had an oxygen content equal to that of surrounding seawater with $P\left(\mathrm{O}_{2}\right)$ of 0.06 bar. This assumes the iron in the fluid is all $\mathrm{Fe}^{2+}$. The half-life decreases to $2.3 \mathrm{~min}$ for the $\mathrm{pH}$ (7.6) of the bottom water in Woodlark Basin (Table 1). Even at these accelerated rates of oxidation, however, almost all of the iron would be dispersed in the water column by the time the oxidation reactions were completed. Voluminous ferric oxyhydroxides dispersed in plumes have been found above areas of active hydrothermal deposition ${ }^{53}$ supporting the notion that most of the vented iron is lost to the seawater column.

Submersible observations during the sampling of the vent fluid at Franklin Seamount suggest that the fluid was exiting at a rate approximately $0.11 \mathrm{~s}^{-1}$ (ref. 54). This is calculated from an estimated rate of emission of $5 \mathrm{~cm} \mathrm{~s}^{-1}$ from an orifice approximately $5 \mathrm{~cm}$ in diameter located on an oxyhydroxide mound at the base of a meter high spire. Based on the calculated oxidation rate of iron for bottom seawater at a $\mathrm{pH}$ of 6.26 and assuming that only the iron oxidized in the first $20 \mathrm{~s}$ (the approximate length of time a fluid is within a $1 \mathrm{~m}$ high chimney) is precipitated, then only $0.4 \mathrm{wt} . \%$ of the iron in the vent fluid would be accumulating within and on the chimneys and mounds. The rest would still be dissolved in the fluid and thus be dispersed by the ocean currents. At these discharge and oxidization rates, about $26 \mathrm{~g}$ of iron would be deposited around that single orifice in one year.

This amount is compared to the calculated oxyhydroxide accumulation rates at Loihi Seamount based upon radiochemical dating reported in Cremer. ${ }^{42}$ The average iron accumulation rate at the hydrothermally active Peles Vent area is $9.9 \mathrm{~g} \mathrm{~cm}^{-2} \mathrm{kyr}^{-1}$ and at the less vigorously venting 1000 Fingers Field is $0.6 \mathrm{~g} \mathrm{~cm}^{-2} \mathrm{kyr}$. A marker, recovered in the Peles Vent area after six months deployment, was found to have accumulated iron at a rate of $23 \mathrm{~g} \mathrm{~cm}^{-2} \mathrm{kyr}^{-1} .42$ 
Assuming the precipitates from that single vent at Franklin Seamount cover an area of one square meter, based on submersible observations of the chimneys, the rate of precipitation is too low by about an order of magnitude when compared to the iron accumulation at Peles Vent, but five times higher than at 1000 Fingers.

Other actively venting orifices were seen in the same oxyhydroxide mound and slowly emitting water was observed from numerous smaller crevices ${ }^{54}$ indicating that the amount of emitted fluid associated with the building of the spire and mound was probably considerably greater than that used in the calculation. Nevertheless, the presence of the large oxyhydroxide deposits at Franklin Seamount suggests that iron is being precipitated in the vent fluid at a much faster rate than that indicated by the kinetic equations. This could occur through: (1) passive or active microbial mediation overcoming the kinetic barriers to ferrous iron oxidation as suggested by previous investigators (e.g., refs. 10, 16 and 55); or (2) by initially precipitated iron acting as a catalyst for the accelerated auto-catalytic hydrothermal deposition of voluminous iron oxyhydroxides. The initial precipitates occurring as mixedvalence ferrosic compounds in the latter process facilitate the decrease in the amount of ferrous iron required to be oxidized to complete the reaction.

Yariv and $\operatorname{Cross}^{56}$ state that the oxidation of an element is catalyzed by the presence, in suspension of colloidal materials, of that same element, and that the surface of a precipitated element will behave as a seed for additional deposition. This auto-catalytic precipitation will occur at a lower supersaturation ratio than that for the element in isolation. As previously mentioned, scanning transmission electron microscope images of amorphous iron oxyhydroxide samples from Franklin Seamount show agglomerated crystallites of $<100 \AA$ diameter at high magnification which suggests that the drawn vent fluid sample contained numerous fine colloidal particles of iron. These particles would be highly reactive to hydrothermal chemical processes.

In summary, kinetic inhibitions are not a major barrier to the initial abiotic chemical oxidation and precipitation of iron at Franklin Seamount. Although the calculated rate of iron oxidation is somewhat too low to explain the large size of the deposits, this rate could be accelerated by auto-catalytic reactions and/or the deposition of mixed valence compounds, as well as by microbial mediation. The predominance of formless textures with no associated bacterial forms in some samples gathered from actively venting chimneys suggests that most of the initial precipitation could be abiotic, however an explanation is required for the dominance of biotic textures in other samples. Nevertheless, calculations show that the kinetic barriers are minimal enough to allow for the formation of seed crystallites that would act as nuclei for the more efficient autocatalytic reactions to follow and investigation into the kinetic and thermodynamic conditions at the vent sites at Franklin Seamount permit the possibility that microbial processes are not necessary for the oxidation of ferrous iron in the fluid. This legitimizes the examination of hydrothermal explanations for the precipitation of the iron.

\section{Chemical conditions of formation}

The sample descriptions and analyses plus an understanding of the microbiology, thermodynamics and kinetics of low temperature vent fluid environments suggest a hydrothermal mechanism is viable for the initial deposition of the Franklin Seamount amorphous iron oxyhydroxides. A geochemical model for the $\mathrm{Fe}-\mathrm{Si}-\mathrm{O}-\mathrm{H}$ system, based on the previously discussed chosen values for fresh hydroxides and using the reactions in Table 3, is graphically presented in Fig. 7. As the temperature and $f\left(\mathrm{O}_{2}\right)$ drop and $\mathrm{pH}$ rises in the vent fluid with dilution by seawater, $\mathrm{Fe}^{2+}$ dissolved in the fluid oxidizes and then precipitates as both ferric and ferrosic hydroxide compounds. Fig. 7 shows that the measured $\mathrm{pH}$ of 6.26 of the vent fluid (Table 1) is similar to that of the calculated triple point for $\mathrm{Fe}^{2+}, \mathrm{Fe}(\mathrm{OH})_{3}$ and $\mathrm{Fe}_{3}(\mathrm{OH})_{8}$ at a $\log f\left(\mathrm{O}_{2}\right)=-44$ at $25^{\circ} \mathrm{C}$. This is consistent with the contention that the precipitation of both ferrosic and ferric iron phases in equilibrium with aqueous ferrous iron appears to be holding the fluid at that triple point. The redox habitats of the iron bacteria Gallionella and Leptothrix (from Fig. 5) plot in the same region. It is possible that some primary microbially mediated oxidation of $\mathrm{Fe}^{2+}$ is aiding the maintenance of the mineral equilibrium between the fluid and the phases since even samples from the most active vents possess some biotic microtextures (Fig. 3c, d).

Genin et al. ${ }^{34}$ constructed similar models using thermodynamic data for various types of green rusts, identified as GR1 and GR2, such as Cl-bearing GR1 $\left(\mathrm{Fe}_{4}(\mathrm{OH})_{8} \mathrm{Cl}\right), \mathrm{CO}_{3^{-}}$ bearing GR1 $\left(\mathrm{Fe}_{6}(\mathrm{OH})_{12} \mathrm{CO}_{3}\right)$ and $\mathrm{SO}_{4}$-bearing GR2 $\left(\mathrm{Fe}_{6}(\mathrm{OH})_{12} \mathrm{SO}_{4}\right)$ in equilibrium with lepidocrocite or goethite and $\mathrm{Fe}^{2+}$. They obtained comparable results to this paper when examined with respect to the iron content in the vent fluid at Franklin Seamount $\left(3.9 \times 10^{-5} \mathrm{~m}\right)$. The ferric and ferrosic

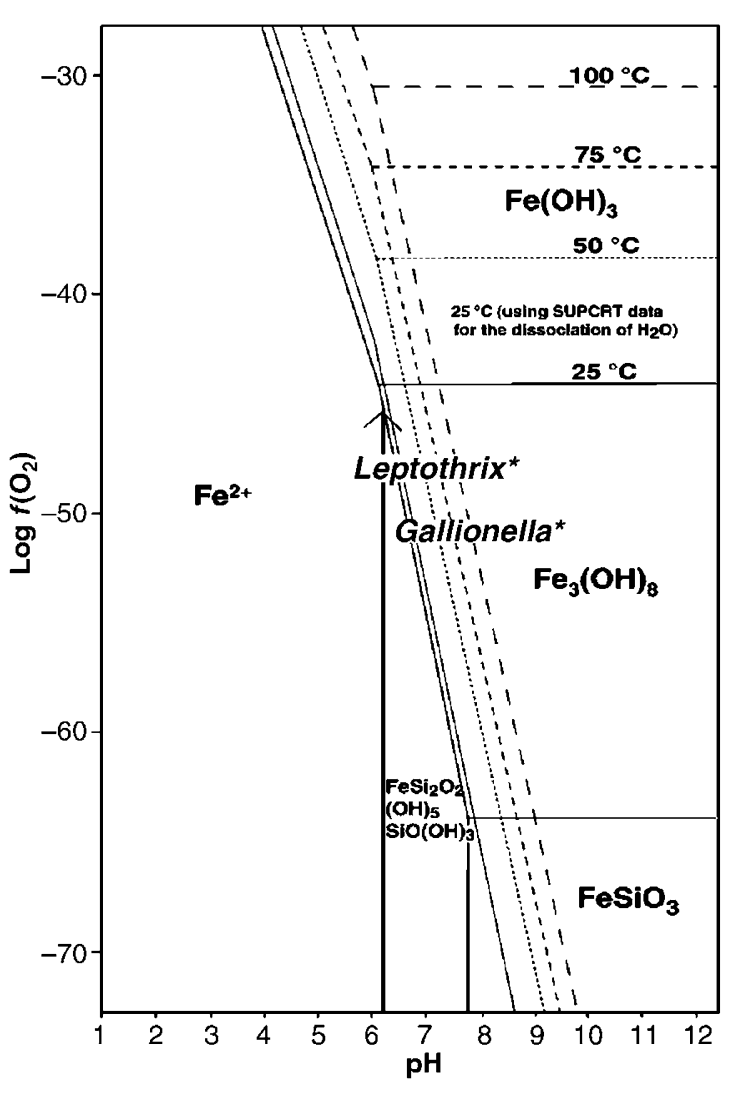

Fig. 7 Phase equilibria of freshly precipitated oxyhydroxides in the Fe-Si-O-H system (1) from Fig. 6 at $25^{\circ} \mathrm{C}, 240$ bar, $\left[\mathrm{Fe}_{\text {total }}\right]=$ $3.9 \times 10^{-5} \mathrm{~m}$ and $[\mathrm{Si}]=3.4 \times 10^{-4} \mathrm{~m}$ which are the physical and geochemical conditions of a vent fluid at Franklin Seamount and at higher temperatures. Calculated and based on the reactions in Table 3 which are drawn from the thermodynamic databases of Sadiq and Lindsay ${ }^{39}$ for $\mathrm{Fe}^{2+}$ and $\mathrm{Fe}_{3}(\mathrm{OH})_{8}$, Langmuir ${ }^{36}$ for $\mathrm{Fe}(\mathrm{OH})_{3}$, and Winters and Buckley ${ }^{43}$ for $\mathrm{FeSiO}_{3}$. The stability fields $\left(^{*}\right)$ of iron bacteria from Fig. 5 are at $25^{\circ} \mathrm{C}$. Dashed lines show change in $\mathrm{Fe}^{2+}$ $\mathrm{Fe}_{3}(\mathrm{OH})_{8}-\mathrm{Fe}(\mathrm{OH})_{3}$ boundaries with increase in temperature. Faint line based on the SUPCRT92 database ${ }^{19}$ for the dissociation of water plotted to show the sensitivity of the $\mathrm{Fe}(\mathrm{OH})_{3}-\mathrm{Fe}_{3}(\mathrm{OH})_{8}$ boundary to minute changes in Gibbs free energies. Calculated with aid of SUPCRT92 program. The arrow represents the upward extrapolation to the $\mathrm{Fe}^{2+}$-solid phases boundaries of the measured $\mathrm{pH}(6.26)$ of the $20-30{ }^{\circ} \mathrm{C}$ vent fluid at Franklin Seamount. 
oxyhydroxides, $\mathrm{Fe}^{2+}$ triple point varies from $\mathrm{pH}$ of 7.8 and $\mathrm{log}$ $f\left(\mathrm{O}_{2}\right)$ of -59 for $\mathrm{Fe}_{4}(\mathrm{OH})_{8} \mathrm{Cl}$, to a $\mathrm{pH}$ of 8.2 and $\log f\left(\mathrm{O}_{2}\right)$ of -64 for $\mathrm{Fe}_{6}(\mathrm{OH})_{12} \mathrm{CO}_{3}$, and to a $\mathrm{pH}$ of 8.5 and $\log f\left(\mathrm{O}_{2}\right)$ of -70 for $\mathrm{Fe}_{6}(\mathrm{OH})_{12} \mathrm{SO}_{4}$. The lower $f\left(\mathrm{O}_{2}\right)$ and higher $\mathrm{pH}$ values in comparison to the results obtained in this paper are mostly due to the choice by Genin et al. of well ordered ferric oxyhydroxide minerals for their model which are not found at Franklin Seamount. ${ }^{34}$ This is consistent with the aforementioned observed trend in Fig. 6 of lower $f\left(\mathrm{O}_{2}\right)$ and higher pH with greater ferric iron oxyhydroxide crystallinity. It is probable, however, that the true composition of ferrosic hydroxide at Franklin Seamount is closer to that of the Clbearing than the $\mathrm{SO}_{4}$ - or $\mathrm{CO}_{3}$-bearing varieties of green rusts because the former is in much higher concentration in seawater than the latter.

Although $\mathrm{Si}(\mathrm{OH})_{4}$ in the fluid was calculated to be undersaturated with respect to amorphous silica at the sampled vent site, Fig. 7 shows that silica can precipitate as $\mathrm{FeSiO}_{3}$ at a $\mathrm{pH}$ higher than 7.7 and lower $f\left(\mathrm{O}_{2}\right)$ than for $\mathrm{Fe}_{3}(\mathrm{OH})_{8}$. This would occur with increased seawater dilution of the fluid providing the redox balance between $\mathrm{Fe}^{2+}$ and the solid phases is maintained. Such an explanation is consistent with the relative rarity of hydrothermal $\mathrm{Fe}-\mathrm{Si}$ smectites as opposed to amorphous iron oxyhydroxides in active vents since most of the time the seawater would flood the system and break down the equilibria before the fluid became very reduced.

The initial abiotic deposition of ferric and ferrosic hydroxides would accelerate the precipitation of the same resulting in a greater accumulation of iron than the $26 \mathrm{~g} \mathrm{yr}^{-1}$ previously calculated. Tunnicliffe and Fontaine ${ }^{57}$ found much of the iron oxyhydroxides at the southern Juan de Fuca vent field were deposited non-specifically as orbs and formless masses suggesting that the oxidation of metals is auto-catalytic.

An understanding of the precipitation of the iron in low temperature systems, however, must account for the evidence of microbial activity at Franklin Seamount and other seafloor oxyhydroxide deposits. It is suggested here that the initially deposited ferrosic hydroxide and ferrous trioctahedral smectite would immobilize the ferrous iron into colloidal particles and thus provide a favorable ferrous substrate for the subsequent growth of iron oxidizing bacteria such as Leptothrix. Most of the filamentous textures observed in the oxyhydroxides probably formed in this fashion. This interpretation is consistent with the dominance of formless iron agglomerates in samples from some of the most active vents and the observation of filaments emanating from the agglomerates (Fig. 3f, g).

The filamentous textures in most samples taken from inactive vents appear very uncontaminated, that is, lacking large amounts of additional deposition of iron on their walls (Figs. 3a, c, d, e, f, g, 4c, d, e). This suggests that the paragenesis of the filaments is relatively late. Additional iron encrustations on sheaths may fill spaces between filaments and eventually coalesce to form irregular iron oxyhydroxide spheres but this texture is uncommon at Franklin Seamount. Difficulties in the identification of filamentous textures arise due to their degradation (Fig. 3h), rather than due to additional iron deposition obscuring the shapes.

This explanation invokes a mostly diagenetic role for the bacteria in the formation of the preserved ferric oxyhydroxides. The ferrosic hydroxides deposited within the relatively aerobic environment of the seawater would also be undergoing abiotic oxidation and transformation to ferric phases. The presence of ferrosic hydroxide on the seafloor is consistent with the observation of the yellowish actively forming deposits at Franklin Seamount. The change to a patchy orange-red coloration in some in situ chimneys on the seafloor is indicative that this transformation, whether microbial or abiotic driven, is occurring rapidly after deposition. Indications of the presence of ferrosic hydroxides therefore would only be found in samples from the most hydrothermally active areas. Iron oxyhydroxide samples obtained from older seafloor deposits would be dominated by filaments. The few hours it took for the gathered samples to darken and turn red on the ship's deck are consistent with oxidation rates of ferrous iron at an atmospheric oxygen concentration and neutral $\mathrm{pH}^{58}$

Comparisons can be made to investigations into mixed valence hydroxides in soil environments. Ponnamperuma et $a .^{25}$ stated that reduced soils which are high in iron and low in both sulfur and organic matter have a grey to green color similar to that of ferrosic hydroxide. Trolard et al. ${ }^{32}$ reported that a waterlogged soil containing green rust once exposed to air was observed to change color rapidly over a number of stages from bluish-grey to greenish-grey to olive to grey over one day. Lindsay and Sadiq ${ }^{59}$ and Genin ${ }^{34}$ concluded, based on their own experiments and others studies, that mixed-valence iron hydroxide acts as a control on many aqueous systems even though the compound is thermodynamically unstable and very reactive in ambient conditions.

In summary, Fig. 7 presents the thermodynamic and microbial environment at Franklin Seamount. Iron oxyhydroxides at Franklin Seamount are formed as a result of a complex interaction of microbial, abiotic, syngenetic and diagenetic processes occurring at the seawater/solid interface. This study demonstrates the importance of avoiding the rigid application of abiotic $v s$. microbial explanations. The complexity of the possible interrelationships between biotic and hydrothermal processes at an iron oxyhydroxide chimney is illustrated in Fig. 8. It should be noted, however, at Franklin Seamount the chemical hydrothermal processes appear to be robust enough that the absence of microbiological activity would slow but not prevent the formation of the deposit. This has implications for understanding the genesis of ancient iron oxide deposits that are interpreted to have formed in an analogous setting.

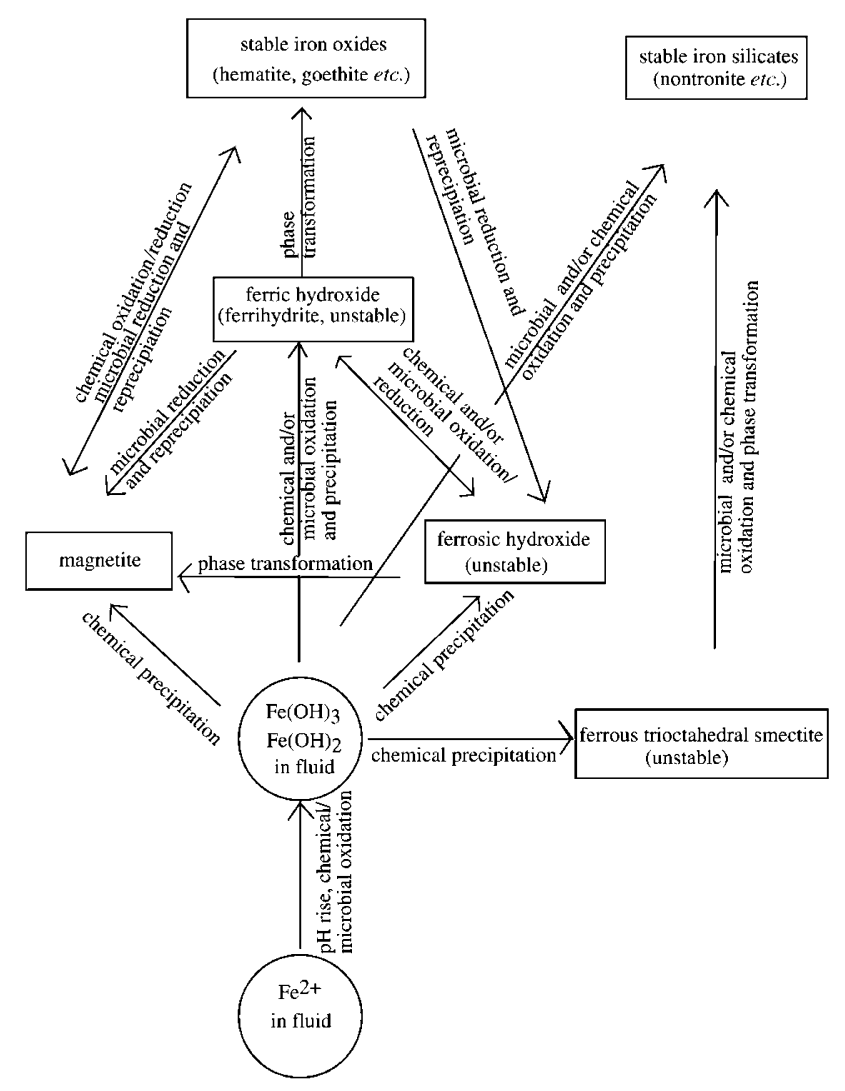

Fig. 8 Various possible biotic and hydrothermal processes at an iron oxyhydroxide chimney on the seafloor. 


\section{Iron oxides in other settings}

\section{Other seafloor deposits}

Low temperature vent fluid samples, defined as those deposited at temperatures of less than $50^{\circ} \mathrm{C}$, have been gathered from numerous seafloor sites such as Loihi Seamount, Hawai; $i^{60}$ Galapagos Rift, Southeast Pacific;, ${ }^{61}$ Axial Seamount, Northeast Pacific; ${ }^{47,61}$ Kasuga Seamount, Northern Mariana Arc; ${ }^{61}$ Guaymas Basin, Gulf of California ${ }^{62}$ and $21^{\circ} \mathrm{N}$, East Pacific Rise. ${ }^{62}$ Fig. 9 presents the measured $\mathrm{pH}$ of the vent fluids at each of these sites in comparison to the calculated $\mathrm{pH}$ of the triple point of $\mathrm{Fe}^{2+}, \mathrm{Fe}(\mathrm{OH})_{3}$ and $\mathrm{Fe}_{3}(\mathrm{OH})_{8}$ for the temperature and iron content of the vent fluids at each of the sites.

At sites dominated by the active deposition of amorphous iron oxyhydroxides, such as at Franklin Seamount, Loihi Seamount and Galapagos, the agreement between the measured and calculated $\mathrm{pH}$ is good, suggesting that the iron in the vent fluid is in equilibrium with the triple point separating the $\mathrm{Fe}^{2+}$ and the solid phases. In contrast, there is little coincidence between the measured and calculated $\mathrm{pH}$ at Kasuga Seamount, Guaymas Basin and one of the sites at $21^{\circ} \mathrm{N}$ suggesting that the iron is not in equilibrium here. For example, the deposits at Kasuga Seamount have considerable elemental sulfur and the fluids contain $\mathrm{H}_{2} \mathrm{~S}$ (ref. 61); at Guaymas Basin the deposits contain voluminous hydrothermal carbonate $^{63}$ and the fluids are very alkaline. ${ }^{62}$ The $\mathrm{Fe}-\mathrm{O}-\mathrm{H}$ buffer of the pH and $f\left(\mathrm{O}_{2}\right)$ at the vent site appears to be operative only in the absence of $\mathrm{H}_{2} \mathrm{~S}$ and $\mathrm{CO}_{2}$. Fig. 9 suggests that the processes described for Franklin Seamount and in soils are occurring at those other seafloor deposits that are dominated by iron oxyhydroxides.

\section{Iron formations}

Comparisons with ancient oxide-facies iron formation are made by modeling geochemically the mineral equilibria of phases that are postulated to be stable analogues of those found on the modern seafloor. Klein and Bricker ${ }^{64}$ conducted a detailed thermodynamic study of Proterozoic iron formation using minerals considered to be early diagenetic in origin. These mineral equilibria were recalculated from the Klein and Bricker free energies using the iron and silicon contents in the

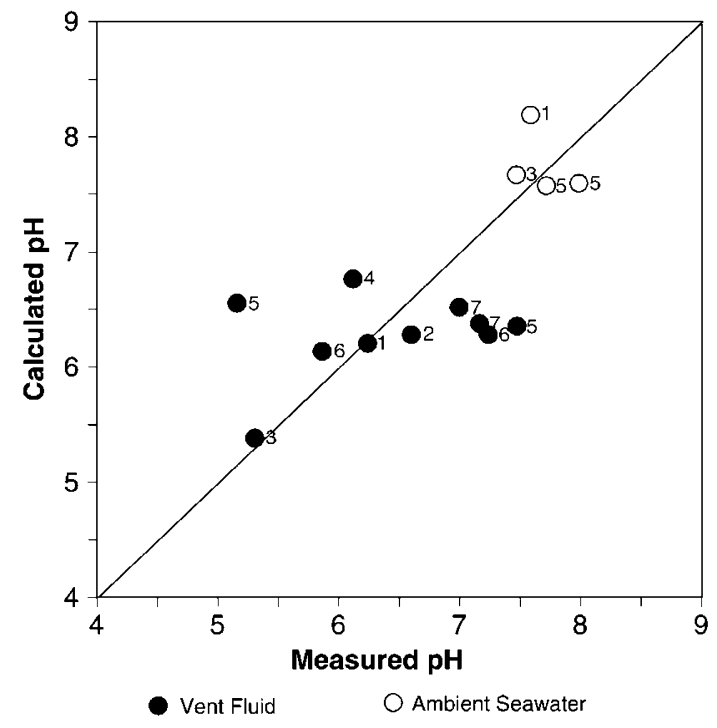

Fig. 9 Calculated $\mathrm{pH}$ of the intersection point for $\mathrm{Fe}^{2+}, \mathrm{Fe}_{3}(\mathrm{OH})_{8}$ and $\mathrm{Fe}(\mathrm{OH})_{3}$ mineral equilibria for compositions of various low temperature vent fluids $v s$. the actual measured $\mathrm{pH}$ of the vent fluid at the site based upon data presented in the literature. 1 Franklin Seamount (ref. 5), 2 Galapagos Rift (ref. 61), 3 Loihi Seamount (ref. 60), 4 Axial Seamount (ref. 47), 5 Kasuga Seamounts (ref. 61), 6 21N East Pacific Rise (ref. 62), 7 Guaymas Basin (ref. 62). vent fluid from Franklin Seamount in Table 1 and plotted in Fig. 10. The results suggest that the mixed valence phase magnetite would predominate if the seafloor oxyhydroxides were preserved unoxidized, providing $\mathrm{Fe}(\mathrm{OH})_{3}$ is in equilibrium with magnetite. Magnetite is commonly a major constituent in Precambrian iron-formation. ${ }^{65}$ Primary nontronite could be replaced by stilpnomelane or greenalite. ${ }^{64,66}$ Considerable amounts of stilpnomelane are found in the Key Tuffite, a silica-iron exhalative horizon lateral to the Archean Matagami Lake massive sulfide deposit in north-western Quebec (Boyd, unpublished data).

Hematite forms from the slow dehydration or thermal transformation of ferrihydrite. ${ }^{27}$ Carlson and Schwertmann ${ }^{67}$ found that this transformation is inhibited by the incorporation of silicon into the material. The amorphous iron oxyhydroxides from Franklin Seamount contain considerable amounts of silicon intimately associated with the iron, ${ }^{8}$ so it would be expected that the transformation to magnetite from ferrosic hydroxides would occur much more rapidly than the formation of hematite from ferrihydrite. This is supported by the near absence of preserved ferrosic hydroxide in nature in contrast with the widespread occurrence of ferrihydrite and magnetite.

Schwab and Lindsay ${ }^{26}$ determined that $\mathrm{Fe}(\mathrm{OH})_{3}$ (ferrihydrite) and magnetite together are more stable relative to $\mathrm{Fe}_{3}(\mathrm{OH})_{8}$, so the former two phases should replace the latter. The result is that magnetite in iron formation is probably not in equilibrium with hematite, but rather with its precursor $\mathrm{Fe}(\mathrm{OH})_{3}$. The phase boundary between hematite and magnetite (dashed line in Fig. 10) is at such a low $f\left(\mathrm{O}_{2}\right)$ that the latter's stability field is usurped by iron silicates. The boundary between goethite and magnetite is similarly at a very low $f\left(\mathrm{O}_{2}\right) .{ }^{55}$. Therefore, goethite or hematite can precipitate with or replace magnetite only at very low $\mathrm{Si}$ concentration in an extremely reduced environment, so it would be expected that

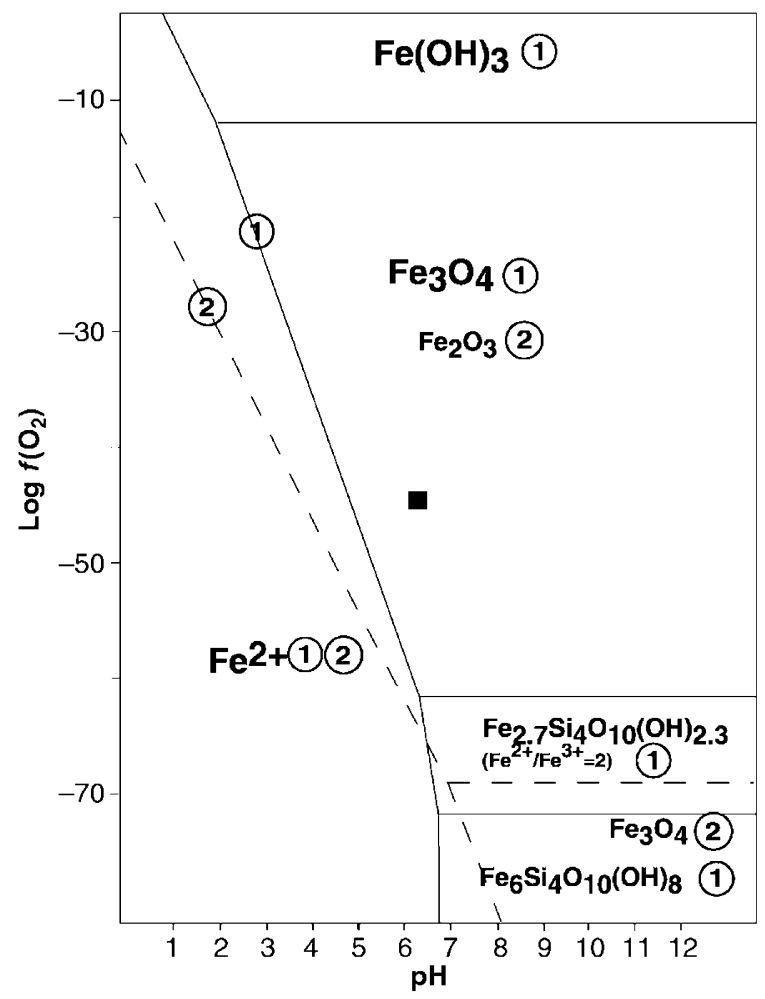

Fig. 10 Phase equilibria of ancient iron-formation at $25^{\circ} \mathrm{C}$ in the $\mathrm{Fe}-$ $\mathrm{Si}-\mathrm{O}-\mathrm{H}$ system using composition of Franklin Seamount vent fluid $\left(\left[\mathrm{Fe}_{\text {total }}\right]=3.9 \times 10^{-5} \mathrm{~m}\right.$ and $\left.[\mathrm{Si}]=3.4 \times 10^{-4} \mathrm{~m}\right)$. (1) Boundaries based on free energy data from Klein and Bricker. ${ }^{64} \mathrm{Fe}^{3}(\mathrm{OH})_{8}$ has converted to $\mathrm{Fe}_{3} \mathrm{O}_{4}$ while $\mathrm{Fe}(\mathrm{OH})_{3}$ persists unstably (see text). (2) Boundaries based on $\mathrm{Fe}_{3} \mathrm{O}_{4}$ in equilibrium with $\mathrm{Fe}_{2} \mathrm{O}_{3}$. Closed square represents location of Franklin Seamount vent fluid from Fig. 7. 
the occurrence of magnetite would be rare in iron formation if this were its means of formation. However, as magnetite is a major constituent of banded iron formation these conditions for replacement must not have prevailed.

As shown in Fig. 8, hematite originates from ferrihydrite formed as a by-product to the crystallization of magnetite, and/ or due to the microbial or hydrothermal oxidation of ferrosic hydroxides and/or precipitated directly from hydrothermal solutions under aerobic conditions. Klein and Bricker ${ }^{64}$ noted that the calculated $\mathrm{Eh}-\mathrm{pH}$ equilibria for magnetite could be too wide due to a lack of thermodynamic data on its precursor. However, the results of this investigation suggest that the authors successfully modeled the early diagenetic mineral assemblages of iron formation with the ferric hydroxides forming in equilibrium with magnetite.

The evidence that ferrosic hydroxide and ferrous trioctahedral smectite are precipitating directly on the seafloor provides an insight into the mineral assemblages of Algoma-type Archean banded iron formation (BIF). Magnetite in BIF could be derived from ferric iron reducing bacteria; ${ }^{68}$ however, a suboxic to anoxic seafloor environment, combined with a paucity of microbial activity would also preserve magnetite and iron silicates such as greenalite. An increase in $f\left(\mathrm{O}_{2}\right)$, and/or microbial activity, would result in the dominance of hematite consistent with that found in ironstones of Cenozoic and Mesozoic age ${ }^{65}$ and iron exhalites associated with massive sulfides such as "tetsusekiei" flanking and overlying Kuroko massive sulfide deposits in Japan. ${ }^{69}$ The above explanation is consistent with both the gradual oxygenation of the atmosphere and the evolution of the earth's biosphere since the Archean. According to Klein ${ }^{70}$ the average chemical compositions of BIF from 3.8 to $1.8 \mathrm{Ga}$ (billion years) are very similar with a large amount of the iron occurring as $\mathrm{Fe}^{2+}$ while $95 \%$ of the total iron in Phanerozoic BIF, deposited between 0.8 to $0.6 \mathrm{Ga}$, is $\mathrm{Fe}^{3+}$.

An understanding of the role of iron bacteria in modern vents has direct bearing on the interpretation of their fossils in ancient rocks. Duhig et $a l^{71}$ describe the preservation of abundant microbial fossils and iron agglomerates in unmetamorphosed Cambrian silica-iron exhalites lateral to a massive sulfide deposit. The authors suggest that iron oxidizing bacteria mediated the deposition of the iron by catalyzing the oxidation of the $\mathrm{Fe}^{2+}$ in the fluid to $\mathrm{Fe}^{3+}$. Iron mineralization bound within and on bacterial cell fossils have been detected in $2.0 \mathrm{Ga}$ red chert from the Gunflint Formation. ${ }^{72}$ Sub-greenschist facies ironstone pods and BIF in the Archean Barberton greenstone belt are dominated by ferric oxides, but also contain early magnetite and indications that hematite and goethite pseudomorphed euhedral magnetite. ${ }^{73}$ Delicate features suggestive of relict hydrothermal discharge such as chimney structures, honeycomb-like cavities and fluid-flow channels were identified in the well preserved Barberton rocks, but petrographic studies found no indication of microfossils. Fossils of filament-forming microbes up to 3.5 billion years old have been reported, ${ }^{74}$ although little is known how common their occurrence was during the Archean.

Previous studies have proposed that the amorphous iron oxyhydroxides were precipitated, directly or indirectly, due to microbial activity and suggest this may have played an important role in the formation of BIF. However, our investigation cautions that microbial micro-textures in ancient BIF cannnot be assumed to be primary. Instead, they could have formed by early diagenetic reactions similar to those in the oxyhydroxide deposits at Franklin Seamount.

\section{Conclusions}

Amorphous iron oxyhydroxides gathered from dormant and actively venting chimneys on the seafloor at Franklin
Seamount contain volumetrically significant filamentous microbial features, although apparently non-bacterial agglomerates are also common. Spatial relationships between the two microtextures suggest that the iron-microbe filaments are either forming subsequent to or together with the agglomerates.

The $f\left(\mathrm{O}_{2}\right)$ of low temperature vent fluids emanating from hydrothermally active chimneys at Franklin Seamount may be much lower than the surrounding seawater. This is based on the in situ observation that yellow mixed-valence ferrosic hydroxide $\left[\mathrm{Fe}_{3}(\mathrm{OH})_{8}\right]$, red-orange ferric hydroxide $\left[\mathrm{Fe}(\mathrm{OH})_{3}\right]$ and light green ferrous trioctahedral smectite appear to be precipitating on the surface of active chimneys coincident with the observation in the samples of fossils of Leptothrix and Gallionella, which prefer low $f\left(\mathrm{O}_{2}\right)$ habitats. These observations are consistent with investigations into the thermodynamics of low temperature iron systems which show that, with increased cooling by mixing with seawater, the $f\left(\mathrm{O}_{2}\right)$ of the fluid will drop to extremely low levels. In addition, the measured $\mathrm{pH}$ of a vent fluid sample (6.26) obtained from a chimney is similar to the $\mathrm{pH}$ of the triple point for $\mathrm{Fe}^{2+}, \mathrm{Fe}_{3}(\mathrm{OH})_{8}$ and $\mathrm{Fe}(\mathrm{OH})_{3}$ which is calculated to occur at a $\log f\left(\mathrm{O}_{2}\right)$ of -44 . Consideration of the thermodynamics and kinetics of iron in the vent fluid suggests that large amounts of amorphous iron oxyhydroxides are capable of precipitating by a combination of abiotic hydrothermal processes. Microbial mediation, however, possibly played a diagenetic role in transforming ferrosic hydroxides to ferric hydroxides resulting in older chimneys being dominated by filamentous textures.

Comparisons with experiments conducted on iron-rich soils and analyses of fluids gathered from actively venting oxyhydroxide chimneys at other seafloor sites provide supporting evidence of the importance of iron species and phases in the redox equilibria of low temperature iron systems. Comparisons with thermodynamic calculations of mineral equilibria in ancient iron formation suggest that the processes which are forming seafloor oxyhydroxide deposits today can be applied to understanding the origin of ancient BIF. Abundant magnetite and a relative paucity of microfossils in Archean iron formation are consistent with the preservation of the primary anoxic depositional environment. In contrast, hematite and abundant microfossils in Phanerozoic BIF are primarily diagenetic in origin reflecting their aerobic and microbial-rich surroundings that resulted in the oxidation of the initially precipitated ferrosic hydroxides.

Future work is needed to confirm the presence of ferrosic hydroxides or natural green rusts in actively venting low temperature sulfur-free springs by collecting samples of the associated iron hydroxide material in anaerobic chambers.

\section{Acknowledgements}

Samples from Franklin Seamount were obtained by the submersible supported Soviet Union-Papua New GuineaAustralia-Canada (SUPACLARK) expedition. We thank our numerous colleagues who assisted with the expedition and subsequent laboratory research. Ray Binns is thanked for his detailed submersible observations. Grant Ferris and Greg Anderson provided guidance in many aspects of the micro biological and geochemical research, respectively. The research was supported by grants to Scott from the Natural Sciences and Engineering Research Council of Canada and Bank of Nova Scotia.

\section{References}

1 P. A. Rona and S. D. Scott, Econ. Geol., 1993, 88.

2 R. Hekinian, M Hoffard, P. Larque, J. L. Cheminee, P. Stoffers and D. Bideau, Econ. Geol., 1993, 88.

3 T. Boyd, S. D. Scott and R. Hekinian, Resource Geol. Special Iss., 1993, 17. 
4 A. Lisitsin, R. A. Binns, Yu. A. Bogdanov, S. D. Scott, L. P. Zonenshayn, V. V. Gordeyev, Ye. G. Gurvich, K. G. Murav'yev and V. V. Serova, Int. Geol. Rev., 1991, 33.

5 R. A. Binns, S. D. Scott, Y. A. Bogdanov, A. P. Lisitsin, V. V. Gordeev, E. G. Gurvich, E. J. Finlayson, T. Boyd, L. E. Dotter, G. E. Wheller and K. G. Muravyev, Econ. Geol., 1993, 88.

6 V. Benes, S. D. Scott and R. A. Binns, J. Geophys. Res., 1994, 99.

7 B. Taylor, A. Goodliffe, F. Martinez and R. Hey, Nature, 1995, 374.

8 T. Boyd and S. D. Scott, Can. Mineral., 1999, 37.

9 S. K. Juniper and Y. Fouquet, Can. Mineral., 1988, 26.

10 J. C. Alt, Mar. Geol., 1988, 81

11 D. Fortin, F. G. Ferris and S. D. Scott, Am. Mineral., 1998, 83.

12 J. M. Bigham, U. Schwertmann and L. Carlson, in Biomineralization Processes of Iron and Manganese-Modern and Ancient Environments, ed. H. C. W. Skinner and R. W. Fitzpatrick, CATENA Supplement 21, 1992, p. 219.

13 F. G. Ferris, K. O. Konhauser, B. Lyven and K. Pedersen, Geomicrobiol. J., 1999, 16.

14 F. G. Ferris, T. J. Beveridge and W. S. Fyfe, Nature, 1986, 320.

15 D. Fortin and F. G. Ferris, Geomicrobiology, 1998, 15.

16 F. G. Ferris, in Microbial Sediments, ed. R. E. Riding and S. M. Awramik, Springer-Verlag, Berlin Heidelberg, 2000, p. 121.

17 W. Stumm and J. J. Morgan, Aquatic Chemistry, John Wiley, New York, 3rd edn., 1996.

18 S. D. Scott and R. A. Binns, in Hydrothermal Vents and Processes, ed. L. M. Parson, C. L. Walker and D. Dixon, Geol. Soc. London Spec. Publ., 1995, vol. 187, p. 191.

19 J. W. Johnson, E. H. Oeikers. and H. C. Helgeson, SUPCRIT92, a software package for calculating the standard molal thermodynamic properties of minerals, gases, aqueous species and reactions from 1 to 5000 bars and 0 to $1000^{\circ} \mathrm{C}$, Earth Sciences Department, Lawrence Livermore National Laboratory, 1991.

20 A. Decarreau and D. Bonnin, Clay Miner., 1991, 21.

21 D. G. Lundgren and W. Dean, in Biogeochemical Cycling of Mineral-Forming Elements, ed. P. A. Trudinger and D. J. Swaine, Elsevier. Amsterdam, 1979, p. 211

22 E. G. Mulder and M. H. Deinema, in The Prokaryotes: a Handbook on Habitats, Isolation and Identification of Bacteria, ed. M. P. Starr, H. G. Stolp, H. G. Truper, A. Balows and H. G. Schlegel, Springer-Verlag, New York, 1981, p. 425.

23 H. H. Hanert, in The Prokaryotes: a Handbook on Habitats, Isolation and Identification of Bacteria, ed. M. P. Starr, H. G. Stolp, H. G. Truper, A. Balows and H. G. Schlegel, Springer-Verlag, New York, 1981, p. 509.

24 W. L. Lindsay, Chemical Equilibria in Soils, John Wiley \& Sons, New York, 1979

25 F. N. Ponnamperuma, E. M. Tianco and T. Loy, Soil Sci., 1967, 103.

26 A. P. Schwab and W. L. Lindsay, Soil Sci. Soc. Am. J., 1983, 47.

27 U. Schwertmann and R. M. Cornell, Iron Oxyhydroxides in the Laboratory Preparation and Characterization, VCH Publishers, Inc., New York, 1991.

28 K. M. Towe and W. F. Bradley, J. Colloid Interface Sci., 1967, 24.

29 F. W. Chukhrov, B. B. Zvyagin, L. P. Ermilova and A. I. Gorshov, 1973, New data on Fe-silica oxyhydroxides in the weathering zone, in Proc. Int. Clay Conf., 1970, ed. J. M. Serratosa, Div. de Ciencias C.S.I.C., Madrid, 1973.

30 R. Eggleton and R. W. Fitzpatrick, Clays Clay Miner., 1988, 36.

31 T. V. Arden, J. Chem. Soc., 1950, 53.

32 F. Trolard, J. M. R. Genin, M. Abdelmoula, G. Bourrie, B. Humbert and A. Herbillon, Geochim Cosmochim Acta, 1997, 61.

33 H. S. Thind and D. S. Chahal, Agricult. Sci. Soc. Cambridge, 1983, 101.

34 J. M. R. Genin, G. Bourrie, F. Trolard, M. Abdelmoula, P. Refait, A. Jaffrezic, V. Maitre, B. Humbert and A. Herbillon, Environ Sci Technol., 1998, 132

35 H. C. Helgeson, J. M. Delany, H. W. Nesbitt and D. K. Bird, Am. J. Sci., 1978, 278-A

36 D. Langmuir, US Geol. Surv. Prof. Pap., 1969, 650-B.

37 H. C. B. Hansen, O. K. Borggaard and J. Sørensen, Geochim. Cosmochim. Acta, 1994, 58.

38 J. K. Fredrickson, J. M. Zachara, D. W. Kennedy, H. Dong, T. C. Onstott, N. W. Hinman and L. Shu-Mei, Geochim. Cosmochim. Acta, 1998, 62.

39 M. Sadiq and W. L. Lindsay, Colorado State Univ. Tech. Bull., 1979, 134.
40 P. N. von Schindler, W. Michaelis and G. Feitknecht, Helvetica Chim. Acta, 1963, 46.

41 D. A. Dzombak and F. M. Morel, Surface Complexation Modeling Hydrous Ferric Oxyhydroxide, John Wiley \& Sons, New York, 1990.

42 M. D. Cremer, Geochemistry of Hydrothermal Deposits from the Summit Region of Loihi Seamount, Hawaii, Unpublished MSc Thesis, University of Hawaii, Hawaii, USA, 1994.

43 G. V. Winters and D. E. Buckley, Geochim. Cosmochim. Acta, 1986, 50.

44 H. Harder, Chem. Geol., 1976, 18.

45 D. R. Kester, in Chemical Oceanography, ed. J. P. Riley and G. Skirrow, Academic Press, London, 1975, p. 498

46 K. L. von Damm, Annu. Rev. Earth Planet. Sci., 1990, 18.

47 M. D. Hannington, P. M. Herzig and S. D. Scott, in Gold Metallogeny and Exploration, ed. R. P. Foster, Blackie, London, 1991, p. 249.

48 T. S. Bowers, K. L. Von Damm and J. M. Edmond, Geochim. Cosmochim. Acta, 1985, 49

49 M. D. Hannington and S. D. Scott, Can. Mineral., 1988, 26.

50 T. S. Bowers, A. C. Campbell, C. I. Measures, A. J. Spivack, M. Khadam and J. M. Edmond, J. Geophys. Res., 1988, B93.

51 W. Stumm and J. J. Morgan, Aquatic Chemistry: an Introduction Emphasizing Chemical Equilibria in Natural Waters, John Wiley \& Sons, New York, 2nd edn., 1981.

52 F. J. Millero, S. Sotolongo and M. Izaguirre, Geochim. Cosmochim. Acta, 1987, 51

53 K. H. Coale, C. S. Chin, G. J. Massoth, K. S. Johnson and E. T. Baker, Nature, 1991, 352

54 R. A. Binns, Report on SUPACLARK Dive 7 on Mir-2 Submersible: Franklin Seamount, Woodlark Basin PNG, CSIRO Division of Exploration Geoscience Restricted Report 140R, Australia, 1990.

55 H. C. W. Skinner and R. W. Fitzpatrick, in Biomineralization Processes of Iron and Manganese-Modern and Ancient Environments, ed. H. C. W. Skinner and R. W. Fitzpatrick, CATENA Supplement 21, 1992, p. 1.

56 S. Yariv and H. Cross, Geochem. Colloid Syst., Springer-Verlag, New York, 1979.

57 V. Tunnicliffe and A. R. Fontaine, J. Geophys. Res., 1987, 92B.

58 W. Davidson and G. Seed, Geochim. Cosmochim. Acta, 1983, 47.

59 W. L. Lindsay and M. Sadiq, Sci. Total Environ., 1983, 28.

60 D. M. Karl, G. M. McMurtry, A. Malahoff and M. O. Garcia, Nature, 1988, 335

61 G. M. McMurtry, P. N. Sedgewick, P. Fryer, D. L. Vonderhaar and H. W. Yeh, Earth Planet. Sci. Lett., 1993, 114

62 K. L. von Damm, Chemistry of submarine hydrothermal solutions at $21^{\circ} \mathrm{N}$, East Pacific Rise and Guaymas Basin. Gulf of California, Unpublished PhD Thesis, Woods Hole, Mass., USA, Woods Hole Oceanographic Institution-Massachusetts Institute of Technology, 1983.

63 J. M. Peter and S. D. Scott, Can. Mineral., 1988, 26.

64 C. Klein and O. P. Bricker, Econ. Geol., 1977, 72.

65 G. A. Gross, in Canadian Mineral Deposit Types: A Geological Synopsis, ed. O. R. Eckstrand, Geological Survey of Canada Economic Geology Report 36, 1984, p. 16.

66 C. Klein and R. P. Fink, Econ. Geol., 1976, 71.

67 L. Carlson and U. Schwertmann, Geochim. Cosmochim. Acta, 1981,45 , p. 421-429.

68 D. R. Lovley, in Biomineralization Processes of Iron and Manganese-Modern and Ancient Environments, ed. H. C. W. Skinner and R. W. Fitzpatrick, CATENA Supplement 21, 1992, p. 101

69 S. I. Kalogeropoulos and S. D. Scott, in The Kuroko and Related Volcanogenic Massive Sulfide Deposits, ed. H. Ohmoto and B. J. Skinner, Economic Geology Monograph 5, 1983, p. 412

70 C. Klein, Geological Association of Canada-Mineralogical Association of Canada Waterloo 94 Program With Abstracts, 1994, 19.

71 N. C. Duhig, J. Stolz, G. J. Davidson and R. R. Large, Econ. Geol., 1992, 87.

72 K. Tazaki, F. G. Ferris, R. G. Wiese and W. S. Fyfe, in Proceedings of the 9th International Clay Conference: Science and Geology, ed. V. C. Farmer and Y. Tardy, 1990, p. 35.

73 C. J. D. Ronde, M. J. D. Wit and E. T. C. Spooner, Geol. Soc. Am. Bull., 1994, 106.

74 K. A. Svitil, Discovery, 1994, 15.

75 R. M. Garrels and C. L. Christ, Solutions, Minerals and Equilibria, Harper \& Row, New York, 1965. 